Mycologia, 107(6), 2015, pp. 1233-1253. DOI: 10.3852/15-021

(C) 2015 by The Mycological Society of America, Lawrence, KS 66044-8897

\title{
Disentangling the complex of Lichenothelia species from rock communities in the desert
}

\author{
Lucia Muggia $^{1}$ \\ Department of Life Science, University of Trieste, Via L. \\ Giorgieri 10, Trieste, Italy \\ Institute of Plant Sciences, Karl-Franzens-University Graz, \\ Holteigasse 6, A-8010 Graz, Austria \\ Jana Kocourková \\ Czech University of Life Sciences Prague, Faculty of \\ Environmental Sciences, Department of Ecology, Kamýcká \\ 129, Prague 6, 165 21, Czech Republic \\ Kerry Knudsen \\ Czech University of Life Sciences Prague, Faculty of \\ Environmental Sciences, Department of Ecology, Kamýcká \\ 129, Prague 6, 165 21, Czech Republic \\ Herbarium, Department of Botany and Plant Sciences, \\ University of California, Riverside, California 92521
}

\begin{abstract}
Rock-inhabiting fungi (RIF) are melanized, meristematic fungi which dwell on and within rocks and have adapted to withstand harsh conditions in extreme habitats worldwide. Their morphological and genetic diversity remained unknown for a long time, but in the past few years culture-dependent and molecular phylogenetic approaches have contributed to uncovering the species richness of these otherwise very inconspicuous fungi. Only a few taxa of RIF develop both sexual reproductive structure (fertile stromata and/or pycnidia) and show multiple life styles, interacting with algae and lichen thalli in different ways. The genus Lichenothelia is one of these: It is characterized by fertile stromata and pycnidia and by species which can grow on and within exposed rocks, optionally associating with algae, with some species also being lichenicolous. The genus Lichenothelia includes up to now 25 species and form a monotypic family (Lichenotheliaceae) and order (Lichenotheliales) in Dothideomycetes. Here we focused on a group of Lichenothelia taxa distributed in the hot arid region of the Sonoran and Mojave Deserts in the Joshua Tree National Park in California. We performed molecular and morphological analyses and culture isolation and considered the ecology of the environmental samples to disentangle five species. We present the revision of two species already described, Lichenothelia calcarea and $L$. convexa, and
\end{abstract}

Submitted 4 Feb 2015; accepted for publication 2 Jul 2015.

${ }^{1}$ Corresponding author. E-mail: lmuggia@units.it, lucia_muggia@ hotmail.com introduce three new taxa to science, L. arida, L. umbrophila and L. umbrophila var. pullata.

Key words: black fungi, cryptic speciation, cultures, morphology, phylogeny

\section{INTRODUCTION}

Black, meristematic, rock-inhabiting fungi (RIFs) dwell on and within exposed rock surfaces and can cope with harsh conditions, out-competing other organisms in extreme habitats (Gorbushina 2003, Sterflinger 2006). These fungi have been reported frequently from hot or cold arid regions around the world (Friedmann 1982, Henssen 1987, Ruibal et al. 2005, Onofri et al. 2007, Selbmann et al. 2013a). The phenotypic plasticity, the production of melanin in the cell walls and slow growth are key traits that enable RIFs to withstand desiccation, high radiations and oligotrophic conditions (Sterflinger 2006).

RIFs commonly occur together with lichens on the same rocks and some rock-inhabiting fungi also were isolated from lichen thalli (Harutyunyan et al. 2008, Selbmann et al. 2013a). The endolithic hyphae of lichens can intertwine with the endolithic hyphae of the black meristematic RIFs (Selbmann et al. 2013). Rock-inhabiting fungi can associate with microalgae, although without forming the stratified structure recognized in lichen thalli. The algal cells are loosely engulfed by the melanized hyphae or grow within the rock, distributed in a layer right below the black fungal mycelium. These associations with algal colonies likely represent a further carbon source for the fungi and resemble primitive forms of lichenization (Kohlmeyer et al. 2004).

Rock-inhabiting fungi are highly variable and often lack reproductive structures, making them difficult to study with morphological-anatomical analysis. Culture-dependent and molecular approaches have helped isolate and identify different strains from the same piece of rock (Selbmann et al. 2005, Ruibal et al. 2009, Muggia et al. 2013) and have contributed further to understanding the morphological diversity of these otherwise inconspicuous fungi (Selbmann et al. 2013b). Recent phylogenetic studies based on multiple nuclear and mitochondrial markers have revealed an unexpected high genetic diversity of RIFs and have succeeded in discovering the phylogenetic affiliation of some identified groups (Ruibal et al. 2009; Muggia et al. 2013; Selbmann et al. 2013a, b; Egidi et al. 2014). The majority of the studied RIFs belong to 
Dothideomycetes and Eurotiomycetes, where they represent the ancestry of mutualistic- and pathogenrich fungal lineages (Gueidan et al. 2008). Egidi et al. (2014) analyzed unnamed cultured strains and collections from different extreme habitats of the world; the authors described 31 new species in 13 new genera and reconstructed their phylogenetic relationship. Some of the genera such as Saxomyces and Cryomyces were found to be remote groups with ancestral positions in the Dothideomycetidae (Selbmann et al. 2005, 2013; Egidi et al. 2014). Other genera on the other hand group taxa from multiple origins (Egidi et al. 2014), indicating the more ample geographic distributions of certain strains.

Lichenothelia is the only genus within Lichenotheliaceae and Lichenotheliales. It includes at the present 25 species (www.mycobank.org/) and represents a lineage with a wobbling position presently in Dothideomycetes (Ertz et al. 2013, Hyde et al. 2013, Muggia et al. 2013, Wijayawardene et al. 2014). Lichenothelia groups fungi with different feeding strategies, including species that can be both parasitic on lichens and grow on and within rocks optionally associating with algae. Because of its multiplicity of living strategies, Lichenothelia was hypothesized to represent a link between rock-inhabiting meristematic fungi and lichenized fungi (Hawksworth 1981, Muggia et al. 2013). Due to the unclear morphological separation, the lichenicolous genus Lichenostigma originally was placed with Lichenothelia in the family Lichenotheliaceae (Henssen 1987). However, molecular data have classified the genera in two different families and orders inside Dothideomyceta (Ertz et al. 2013, Hyde et al. 2013, Muggia et al. 2013). The genus Lichenostigma, together with the genus Etayoa and Phaeococcomyces, belongs to Lichenostigmatales, sister to Arthoniales (Ertz et al. 2013). Lichenostigma is considered to be morphologically distinguished from Lichenothelia species by the way cells divide. In Lichenostigma these cells are spherical and multiply by "budding" instead of by division through the formation of septa as in Lichenothelia (Ertz et al. 2013).

In this paper we focused on a group of Lichenothelia species distributed in the Sonoran and Mojave deserts in the Joshua Tree National Park in California, a hot arid region characterized by wide, flat valleys and rugged isolated mountain ranges. Annual precipitation averages $110.0 \mathrm{~mm}$ with an average low of $10.4 \mathrm{C}$ and average high of 26.4 C (U.S. Climate Data 2014). Daily temperatures often are above $33 \mathrm{C}$. Elevation is 10-1772 $\mathrm{m}$. Creosote bush predominates in the Sonoran Desert whereas Joshua trees predominate in the Mojave Desert. Pinyon pines and junipers occur in areas above $1000 \mathrm{~m}$. The land was transformed from lake-dotted savanna to desert in a relatively short time at end of the Pleistocene (Trent and Hazlett 2002).

Lichenothelia was frequent throughout Joshua Tree National Park and was observed on granites, gneiss and basalt at all elevations within the park. For comparison we also collected Lichenothelia specimens in Europe and studied specimens previously collected from limestone in the Clark Mountains in the Mojave Desert Preserve in California and from Europe in herbaria. On the basis of morphological and molecular analyses we identified two described species and three new taxa. Here we expanded the former study of Muggia et al. (2013) by including the new samples and testing their species recognition on the base of morphological and molecular analyses of specimens and isolated fungal cultures. We further discuss their phylogenetic relationships in a context of species evolution and retention of morphological traits.

\section{MATERIALS AND METHODS}

Sampling._Lichenothelia specimens were collected 2010-2013 and are stored in GZU, UCR and Hb. Mycologicum Kocourková \& Knudsen (Hb. JK \& KK). The specimens come from 98 sites in the Joshua Tree National Park in California (USA.) in the Mojave and Sonoran deserts and from two localities in Europe in the Czech Republic. We attempted to collect only one taxon in each sample. The Lichenothelia fungi grow tightly on the rock and always were collected together with the underneath substrate using a hammer and chisel and placed in paper bags. GPS coordinates were taken of collections and made within 10-100 m radius. Because almost all collections occur within Joshua Tree National Park, only a selection of specimens is cited here. A total of 110 samples were collected and all were considered for morphological analyses; 19 of them were selected for molecular analyses; 11 for culture isolations. Additional specimens and types of Lichenothelia convexa, L. calcarea and unidentified taxa from California and Europe from B, GZU, H, UCR and SBBG also were studied.

Morphological analyses. - Morphological and anatomical characters of both environmental samples and cultured strain were analysed with standard microscopic and photographic techniques. We analysed morphologically all the collected samples, but for each locality we cite only a single specimen. The following morpho-anatomical traits were analyzed in the environmental samples and used for species delimitation: fertile stroma stipitate or not, amyloid reaction of interascal gel with I (Lugol's iodine), presence or absence of slender interascal filaments, ascospore size and septation and morphology of the thallus, especially of the superficial hyphae. Measurements are length by width and exceptional dimensions are placed in parentheses.

The morphological analyses of the cultured strains were performed on 6-10 mo old cultures, and we considered these characters: form of growth, branching of the hyphae and hyphae maturation. Small fragments of the grown mycelium 
were taken, and squashed sections were mounted in water. Images were acquired with a ZeissAxioCam MRc5 digital camera fitted to the microscopes. Both images of growth habit and hyphae structure were digitally optimized with the CombineZM software (open source image processing software available at www.hadleyweb.pwp.blueyonder.co. uk/). The photos were refined with Adobe Photoshop 7.0 and were prepared with CorelDRAW X4.

Structures of samples were studied in water and $10 \% \mathrm{KOH}$ $[\mathrm{K}]$. Amyloid reactions were tested in Lugol's iodine [I] (MERK 109261) without pretreatment with $\mathrm{K}$ and ascus stains were studied with I with or without pretreatment with $\mathrm{K}$. Ascospore measurements were made in water with an accuracy of $0.5 \mu \mathrm{m}$. Macro- and microphotographs were taken with a digital camera Olympus DP72 with Quick Photo Camera 2.3 mounted on an Olympus SZX 7 stereomicroscope and Olympus BX51 light microscope fitted with Nomarski interference contrast. The photos were refined with Adobe Photoshop 11.0 and prepared with CorelDRAW X6.

DNA extraction, amplification and sequencing.-Nineteen environmental specimens and 24 cultures were used for DNA extraction. Only those samples that were successfully sequenced were included in the phylogenetic analyses and are reported herein (TABLE I).

The samples were dissected carefully under the stereo microscope and prepared for DNA extraction. A small group of ascomata or, if these were rare or absent, about $0.5 \mathrm{~cm}^{2}$ of the dry crustose, melanized thalli, were scratched from the rock substrate with a sterile razorblade. The fungal material was always taken from a single area of the rock and transferred into a $1.5 \mathrm{~mL}$ tube; similarly a small part of the culture isolates was taken and transferred into a $1.5 \mathrm{~mL}$ tube. The material was frozen and pulverized with metal beads using a TissueLyserII (Retsch). The DNA was extracted according the protocol of Cubero et al. (1999). The phylogenetic relationships of the Lichenothelia taxa and the cultured strains were studied with sequences of the partial large $28 \mathrm{~S}$ and partial small 18S nuclear rDNA and the 16S mitochondrial rDNA small ribosomal subunits (mt16S). The 28S fragment was amplified in two pieces with primers ITS1F (Gardes and Bruns 1993) and LR5 for the first part and LR3R and LR7 (Vilgalys and Hester 1990) for the second part (http://www. biology.duke.edu/fungi/mycolab/primers.htm). The $18 \mathrm{~S}$ locus was amplified with primers nuSSU0072, nuSSU0852 (Gargas and Taylor 1992) or NS1 (White et al. 1990). The mt16S locus was amplified with primers mtSSU1 and mtSSU3r (Zoller et al. 1999) or MSU7 (Zhou and Stanosz 2001). The amplification of the genes followed touch-down PCR conditions as in previous studies (Muggia et al. 2011, 2013). Both complementary strands were sequenced, and sequencing was run by Microsynth (Vienna, Austria). The sequences were assembled and edited in BioEdit (Hall 1999).

Alignment and phylogenetic analyses. - The identity of the new generated sequences were checked with sequences available in the GenBank database and the taxa that closest matched our sequences were selected for the phylogenetic analyses. In a first analysis (not shown) we included in our dataset taxa representatives of 15 orders of the superclass Dothideomyceta (Dothideomycetes plus Arthoniomycetes, Schoch et al. 2009) to cover the highest species diversity as possible, as performed by Muggia et al. (2013). Second, we reduced the dataset by selecting those orders in which we recovered our newly sequenced samples together with the closest related orders (TABLE I). The majority of the taxa were selected by referring to the recent phylogenetic studies of Ruibal et al. (2009), Muggia et al. (2013) and Hyde et al. (2013). Three species of Arthoniomycetes were chosen as outgroups for the final reduced dataset: Arthonia caesia, Dendrographa leucophaea and Roccella fuciformis. The sequence alignments were prepared manually in BioEdit (Hall 1999), individually for the three loci $28 \mathrm{~S}, 18 \mathrm{~S}$, and mt16S. Introns and ambiguous SNPs were removed from the alignment. In a number of specimens we were unable to generate sequences for all the selected loci and other taxa sequences were not available in GenBank. Samples already analyzed by Muggia et al. (2013) were included again as we succeeded in sequencing one or two of the previously lacking loci (TABLE I).

Combined data of different loci, whether fully or partially congruent, should be considered by inferring organismal phylogeny (Dettman et al. 2003). We therefore, as performed in Kauff and Lutzoni (2002), Miadlikowska et al. (2006) and Muggia et al. (2014), prepared both single-locus and combined datasets. We analyzed the single-locus datasets with a maximum likelihood (ML) approach (Meson-Gamer and Kellogg 1996, Reeb et al. 2004) and the combined dataset using maximum likelihood (ML) and Bayesian approaches. In both approaches the combined dataset was treated in partition by genes $28 \mathrm{~S}, 18 \mathrm{~S}$ and mt16S. The ML analyses were performed with the program RAxML (Stamatakis et al. 2005). Because only a single model of molecular evolution can be used across gene partitions in RAxML, the ML analyses (for single loci and combined datasets) were performed with the GTRMIX model, and 1000 bootstrap replicates were run. The Bayesian Markov chain Monte Carlo (B/MCMC) analyses were run in MrBayes 3.1.2 (Huelsenbeck and Ronquist 2003, Ronquist et al. 2005). The models of molecular evolution applied to each gene partition in the Bayesian analysis were estimated in JModeltest 2.1.4 (Darriba et al. 2012) with the Akaike information criterion (Posada and Crandall 1998). The B/MCMC analysis run with six chains simultaneously, each initiated with a random tree, for 10000000 generations; trees were sampled every 100 generations for a total sample of 100000 trees. Log-likelihood scores against generation time were plotted with Tracer 1.4 (Rambaut and Drummond 2007) to determine when the stationarity of likelihood values had been reached as a guide for setting burn-in (Ronquist et al. 2005). Burn-in was set at 5000000 generations (the first 50000 sampled trees) and a majority-rule consensus tree was calculated from the posterior sample of 50001 trees. The convergence of the chains was confirmed by the convergent diagnostic of the potential scale reduction factor (PSRF), which approached 1 (Ronquist et al. 2005). The phylogenetic trees were visualized in TreeVIEW (Page 1996).

The sequences alignment was deposit at TreeBASE under the accession number TB2:S17369. 


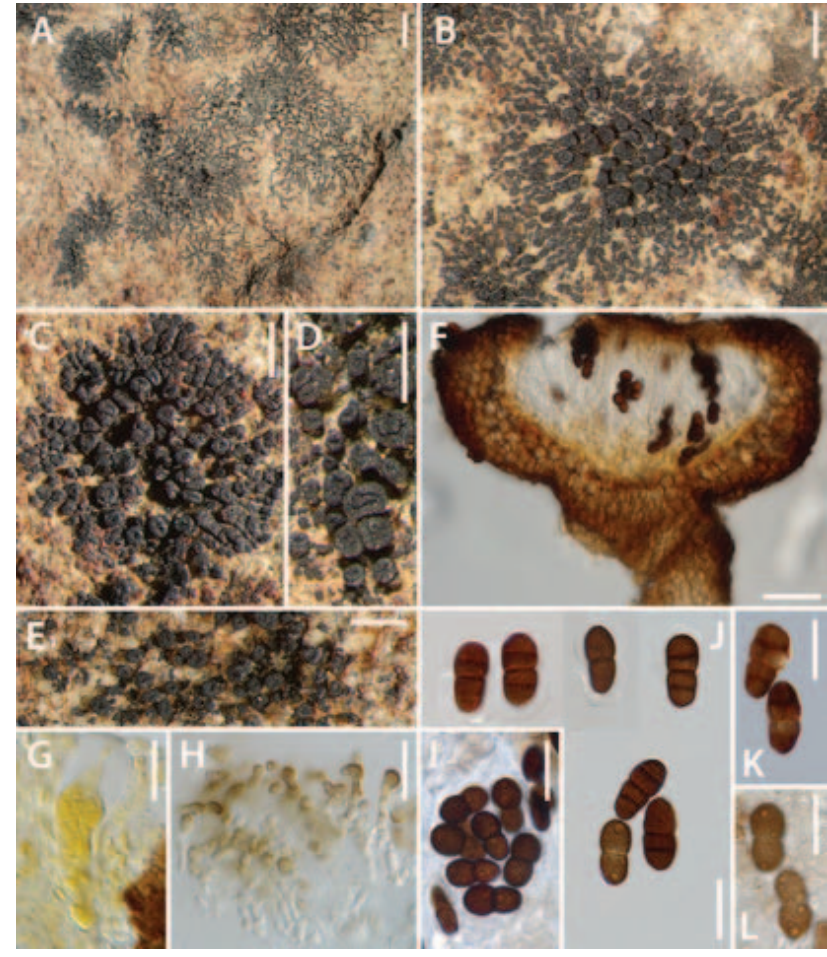

FIG. 1. Lichenothelia arida (Knudsen 12648). A-E. Thallus and fertile stromata. A. Small orbicular of unoriented, dispersed or confluent thin patches. B. Orbicular thallus with long strands, central part with fertile stromata. C. Compact patch. D. Umbonate fertile stromata. E. Thallus lacking strands. F. Vertical section of fertile stroma, with stipe and paraplectenchymatous wall. G. Young ascus in I (Lugol), I- dextrinoid reaction. H. Interascal filaments, widened and brownish at apices. I. Eight-spored, nearly mature ascus. J. Halonate 1-3-septate ascospores. K. Submuriform ascospores. L. Verruculose surface of ascospores. Bars: $A=1$ $\mathrm{mm}, \mathrm{B}-\mathrm{E}=0.5 \mathrm{~mm}, \mathrm{~F}=50 \mu \mathrm{m}, \mathrm{G}-\mathrm{L}=20 \mu \mathrm{m}$.

Culture isolation.-Eleven samples of Lichenothelia, selected among those used for DNA extraction and distinguished by morphological traits, L. arida L1704, L1708, L2161, L2163, L2165, L2168, L2170, L2172, L. calcarea L1799, L. convexa L1609, L. umbrophila L1715, were chosen for culture isolation. The axenic cultures were prepared from up to two mo freshly collected samples. The isolation of the fungi was performed by selecting a small area of the thallus, ca. $1-2 \mathrm{~cm}^{2}$ and washing it by pipetting once with bi-distilled sterile water and three time with Tween 80 to remove the possible external contaminations of bacteria and yeast (Bubrick and Galun 1986). The thallus then was sliced carefully with a sterile razorblade and tiny fragments of the melanized hyphae were taken with a sterile needle and inoculated on agar plates. If the samples presented ascomata, two to four ascomata were dissected and slices were laid on the medium. Up to eight fragments were inoculated on one plate and up to three agar plates were prepared originally for each sample. The agar plate were sealed with parafilm to avoid the desiccation of the medium and were incubated in a growing chamber at $20 \mathrm{C}$, with a light-dark regime of $14: 10 \mathrm{~h}$ with light intensity of $60-100 \mu \mathrm{mol}$ photons $\mathrm{m}^{-2} \mathrm{~s}^{-1}$ and $60 \%$ humidity. The Bold basal medium (BBM; Bischoff and Bold 1963, Bold 1949) was used for the first inocula and ampicillin was added to reduce contaminant bacterial growth. The inocula were checked weekly for contamination. After 3-5 mo the inocula reached about $1-3 \mathrm{~mm}$ diam and it was possible to subculture them and to prepare them for DNA extraction, sequencing and morphological analyses. The subcultures were set on malt yeast (MY, Ahmadjian 1967) and Lilly-Barnett's (LBM, Lilly and Barnett 1951) media. The cultured strains are deposit at the University of Graz in the culture collection of the first author, LM, and at the public culture collection Mycotheca Universitatis Taurinensis (MUT) at the University of Turin (Italy). The cultured strains are reported below with their DNA extraction number and with both collection numbers (LM, MUT).

The DNA extraction protocol followed Cubero et al. (1999); the identity of the cultures was checked by sequencing the same nuclear and mitochondrial loci (28S, 18S, mt16S) selected for the original environmental samples. PCR amplification and sequencing and the morphological analyses were carried out as reported above.

Approach followed for species delimitation.-The description of the Lichenothelia taxa is based on the revision of original species descriptions (Henssen 1987), on type material (B, H, SBBG) and on the identification of monophyletic (or paraphyletic) groups according to phylogenetic species recognition criteria (Hudson and Coyne 2002). We followed these approaches because the majority of the investigated taxa lack clearly differentiable morphological traits and their original description was based on very few or even single specimens (Henssen 1987). In this study we recognized and named a taxon when (i) morphological and ecological traits were shared among the samples and (ii) the analyzed specimens, including the original environmental specimens and their derived cultured strains, built monophyletic or paraphyletic lineages within Lichenotheliaceae both in the single locus and in the combined loci analyses (Bayesian, ML analyses).

\section{Results}

Morphological analyses of environmental samples.-According to the morphological characters analyzed in the environmental samples we recognized five taxa, three of which are described here as new species: Lichenothelia arida sp. nov. (FIG. 1), L. calcarea (FIG. 2), L. convexa (FIG. 3), L. umbrophila sp. nov. (FIG. 4) and L. umbrophila var. pullata sp. nov. (FIG. 5). For each species the results of the morphological analyses are reported in detail in the species description in TAXONOMY below.

Culture isolations.-A total of 136 inocula were prepared. Due to contaminations by fungal moulds, bacteria or algae, the majority of the inocula were discarded and only 22 inocula could be successfully subcultured and used for molecular analyses: six 

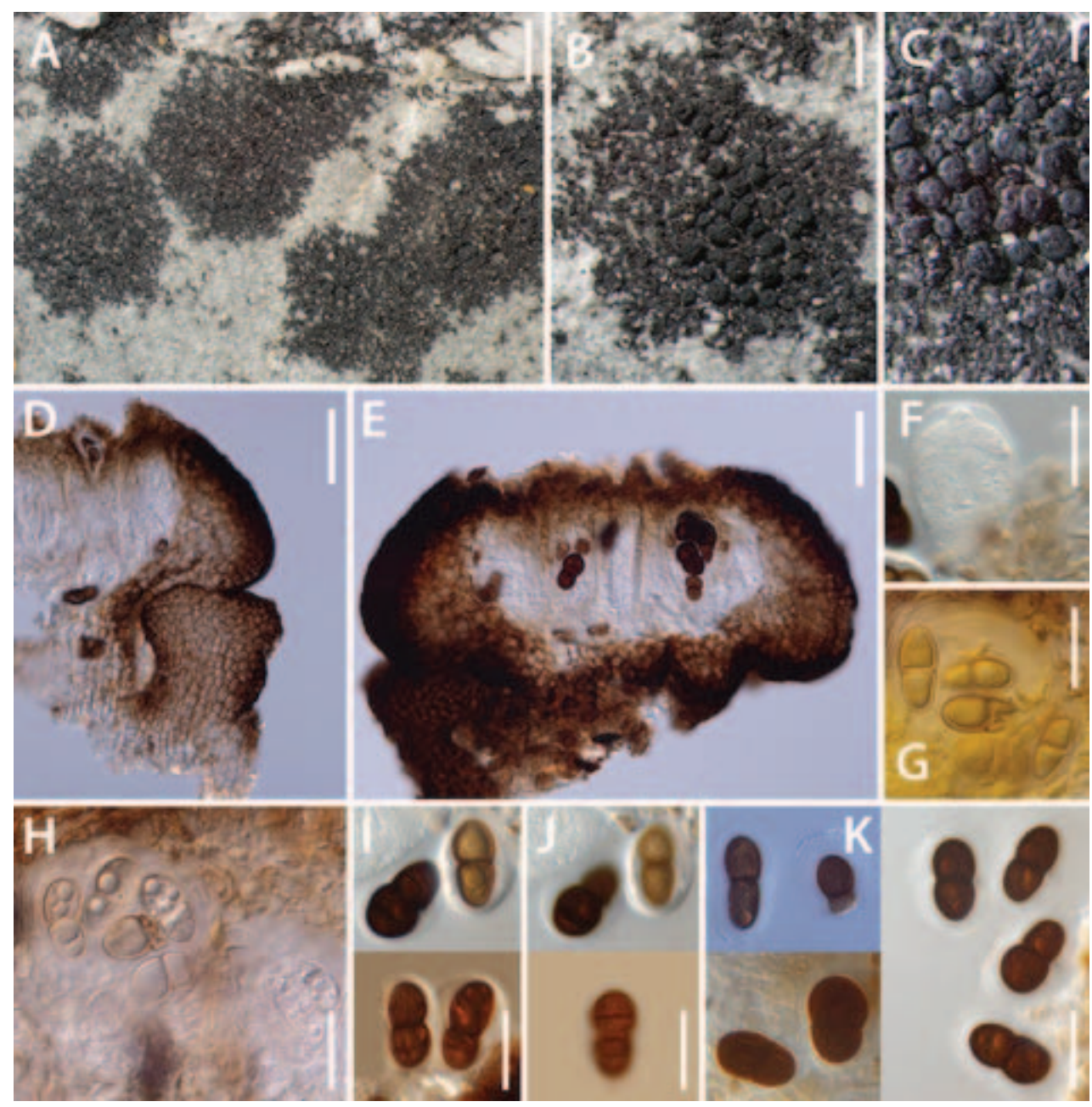

Fig. 2. Lichenothelia calcarea (A-H, K. Knudsen 11444.1; I-K, K. Knudsen 11741). A-C. Thallus and fertile stromata. A. Dispersed to confluent patches. B. Orbicular thallus with clustered fertile stromata in central part, surrounded by radial, net-forming, flat strands. C. Smooth to rough, mostly umbonate, fertile stromata. D. Shortly stipitate stromata. E. Vertical section of fertile stroma, paraplectenchymatous wall. F. Young ascus. G. Ascus in I (Lugol), I- dextrinoid reaction. H. Six-spored young ascus with subhyaline one-septate ascospores. I. Ascospores with wide halo. J. Verruculose 1-3-septate ascospores. K. Variation of ascospores. Bars: $\mathrm{A}=1 \mathrm{~mm}, \mathrm{~B}=0.5 \mathrm{~mm}, \mathrm{C}=0.2 \mathrm{~mm}, \mathrm{D}-\mathrm{K}=20 \mu \mathrm{m}$.

from Lichenothelia arida, four from L. calcarea and 12 from L. convexa. No culture isolation was successful so far from L. umbrophila and L. umbrophila var. pullata. Molecular analyses confirmed the identity of Lichenothelia fungi for 13 inocula, the remaining nine inocula were identified as dothidealean fungi in the class Capnodiales and as rock inhabiting fungi with incerta saedis in Dothideomycetes (FIG. 6, SuPPLEMENTARY FIG. 1).

Multiple inocula, either recognized as Lichenothelia fungi or as other dothidealean fungi, which have been isolated from the same, original Lichenothelia thallus, had identical sequences for the three loci. We selected therefore for the phylogenetic analyses (as follows) only the inocula for which we successfully sequenced at least two loci: They were nine
Lichenothelia (four from L. arida, three from L. convexa and two from L. calcarea) and four non-Lichenothelia fungi.

Pairwise comparisons between the original thallus sequence and the sequence of the inocula were carried out manually, and the phylogenetic analyses confirmed the correct isolation in culture of the fungi Lichenothelia arida L2170, L. calcarea L1799 and L. convexa L1609. For the two inocula, L2198 and L2197, isolated from L. arida L2161 and L2168, respectively, we were not able to compare the sequences data with those of the original thalli because these latter failed in PCR amplification and sequencing. Nevertheless these inocula are recovered within Lichenotheliaceae (FIG. 6) and are considered to be true Lichenothelia fungi. The four not-Lichenothelia strains were obtained 

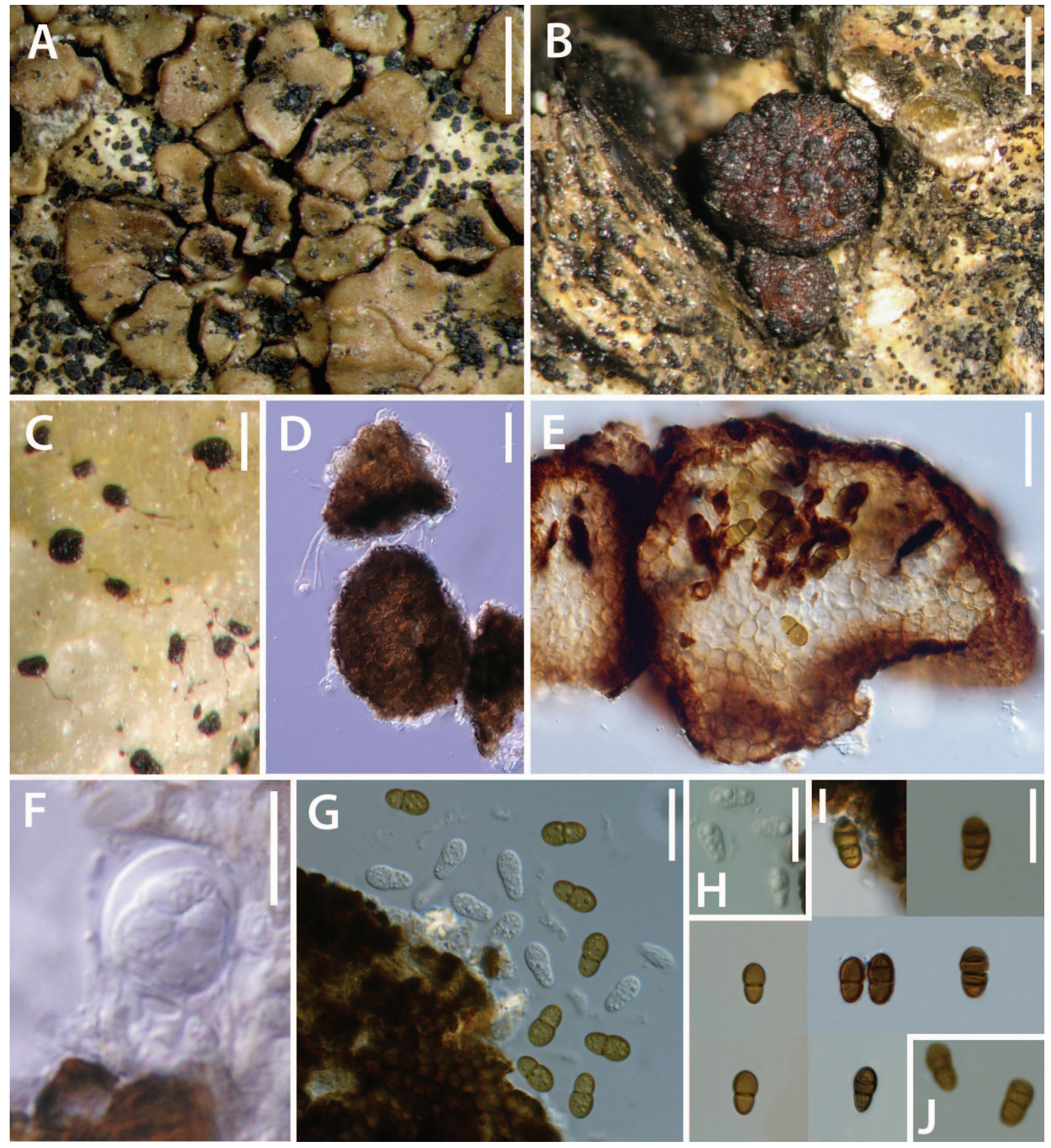

Fig. 3. Lichenothelia convexa (A, E, G-J, J. Kocourková 7404; B-D, F, K. Knudsen et al. 9242). A. L. convexa on Acarospora gallica and on rock. B. Infected apothecium of Polysporina simplex and fertile stromata on rock. C. Fertile stromata on rock with superficial hyphae. D. Stromata connected with hyphae. E. Vertical section of fertile stroma with paraplectenchymatous center. F. Young ascus. G) Young hyaline and brown one-septate, non-halonate ascospores released from eight-spored asci. H. Hyaline, guttulate, occasionally halonate, one- septate ascospores. I. 1-3-septate mature ascospores. J. Verruculose surface of ascospores. Bars: A, B $=0.5 \mathrm{~mm} ; \mathrm{C}=0.2 \mathrm{~mm} ; \mathrm{D}, \mathrm{E}=20 \mu \mathrm{m} ; \mathrm{F}=10 \mu \mathrm{m} ; \mathrm{G}-\mathrm{J}=20 \mu \mathrm{m}$. 


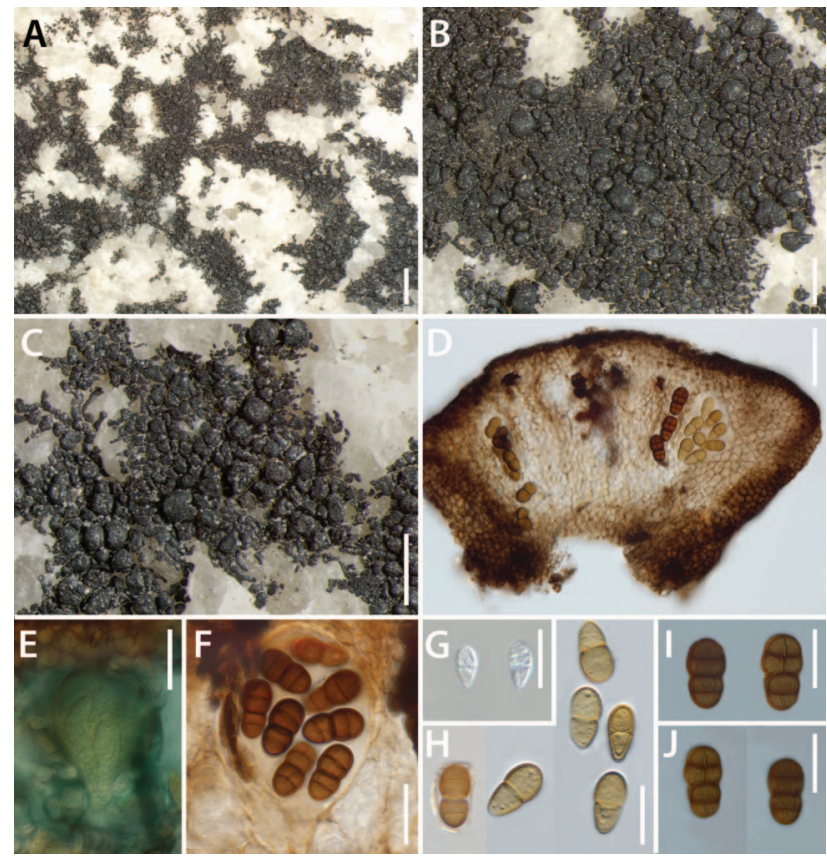

FIG. 4. Lichenothelia umbrophila (A-D, F-G, I-J, Knudsen 16331, holotype; E, G, Knudsen 16329). A-C. Thallus and fertile stromata. A. Thallus formed by irregular patches fusing in net. B. Compact thallus with fertile stromata. C. Compact thallus with fertile stromata and short radiating strands. D. Vertical section of fertile stroma with paraplectenchymatous center. E) Ascus in I (Lugol), I+ amyloid reaction. F. Eight-spored, saccate ascus. G. Young, hyaline, non-halonate, one-septate ascospores. H. Pale brown 1-3septate ascospores, one spore halonate. I. Submuriform ascospores. J. Faintly verruculose surface of ascospores. Bars: $\mathrm{A}=1 \mathrm{~mm} ; \mathrm{B}, \mathrm{C}=0.5 \mathrm{~mm} ; \mathrm{D}=50 \mu \mathrm{m} ; \mathrm{E}-\mathrm{J}=20 \mu \mathrm{m}$.

from L. arida L2161 (strains L2186, L2199) and recovered in Capnodiales and from L. convexa L1609 (strains L1854 and L1855) and recovered as basal to Dothideomycetes (FIG. 6).

Morphological analyses of cultured fungi.-Morphological analyses conducted on the cultured Lichenothelia fungi did not help to clearly differentiate four species. All the cultures present a compact mycelium, partially growing inside the medium. Generally the hyphae are melanized, pale to dark brown, septate, composed by almost isodiametric cells (FIGs. 7, 8), and present meristematic growth and numerous ramifications. The mycelium of L. calcarea (FIG. 7a-1) presents apical cells of the hyphae that commonly generate multiple cells; these are responsible for the meristematic growth and conspicuous branching. The cells are slightly rectangular, either elongate or seeming compressed, with thick wall (FIG. 7i-l). Only dividing cells are isodiametric. Lichenothelia convexa (FIG. $7 \mathrm{~m}-\mathrm{s}$ ) builds a more compact mycelium and the elongate hyphal cells are sometimes joined by thicker, more isodiametric cells. Cultured Lichenothelia arida presents two different morphologies. The fungi cultured from specimen L2170, L2195 and L L2196 (FIG. 8a-d), and that cultured from L2161, L2198 (FIG. 8j-1), have a black mycelium, forming globose colonies with isodiametric cells, which do not arrange in proper hyphae but rather form dense agglomerates (FIG. 8d, k, l) that seldom branch (Fig. 8c, d). On the other hand the fungus cultured from specimen L2168, namely L2197 (FIG. 8e-i) resembles those of L. calcarea and L. convexa with a loose mycelium formed by hyphae with elongated cells and frequent branching.

Phylogenetic analyses.-PCR amplifications performed with the primer pair ITS1F-LR5 targeting the first part of the $28 \mathrm{~S}$ region were not successful. We therefore could include molecular data for the second part of the $28 \mathrm{~S}$ only. We obtained 67 total new sequences (14 for the 28S, 26 for the $18 \mathrm{~S}$ and 27 for the mt16S loci). Only five samples are represented here by the single 18S marker (L2023, L2162, L2165, L2166, L2167). Eight samples are represented by two loci and 15 samples by all three markers. The new sequence data include 27 environmental samples of Lichenothelia spp., three non-Lichenothelia fungi amplified from environmental samples of Lichenothelia spp., nine Lichenothelia cultured strains and four non-Lichenothelia cultured strains. We further included in the present study the four cultured strains L1285-L1288 (Muggia et al. 2013) for which we have successfully sequenced the mtSSU marker.

The phylogenetic relationships of the orders in Dothideomycetes are congruent with previous phylogenetic reconstructions (Ruibal et al. 2009, Schoch et al. 2009, Hyde et al. 2013, Muggia et al. 2013, Egidi et al. 2014) and their corresponding clades are here highly or fully supported. The order Lichenotheliales is recovered monophyletic in each single locus (SuPPLEMENTARY FIG. 1) and in the multilocus analyses (FIG. 6); although it still does not receive support as in former studies (Hyde et al. 2013, Muggia et al. 2013, Wijayawardene et al. 2014). The morphologically recognized Lichenothelia species are recovered either monophyletic or paraphyletic. The single-locus phylogenetic reconstructions show only little incongruence in tree topologies, addressed to the uneven taxon sampling due to lack of sequence data. The phylogenetic inference based on the 28S locus places a clade of Lichenothelia sp., one isolated from specimen of L. calcarea (L1799) and three from specimens of $L$. arida (the specimens L1708 and two culture isolates, L2195 and L2196) outside Lichenotheliaceae and closely related to Lichenostigmatales. Further specimens 


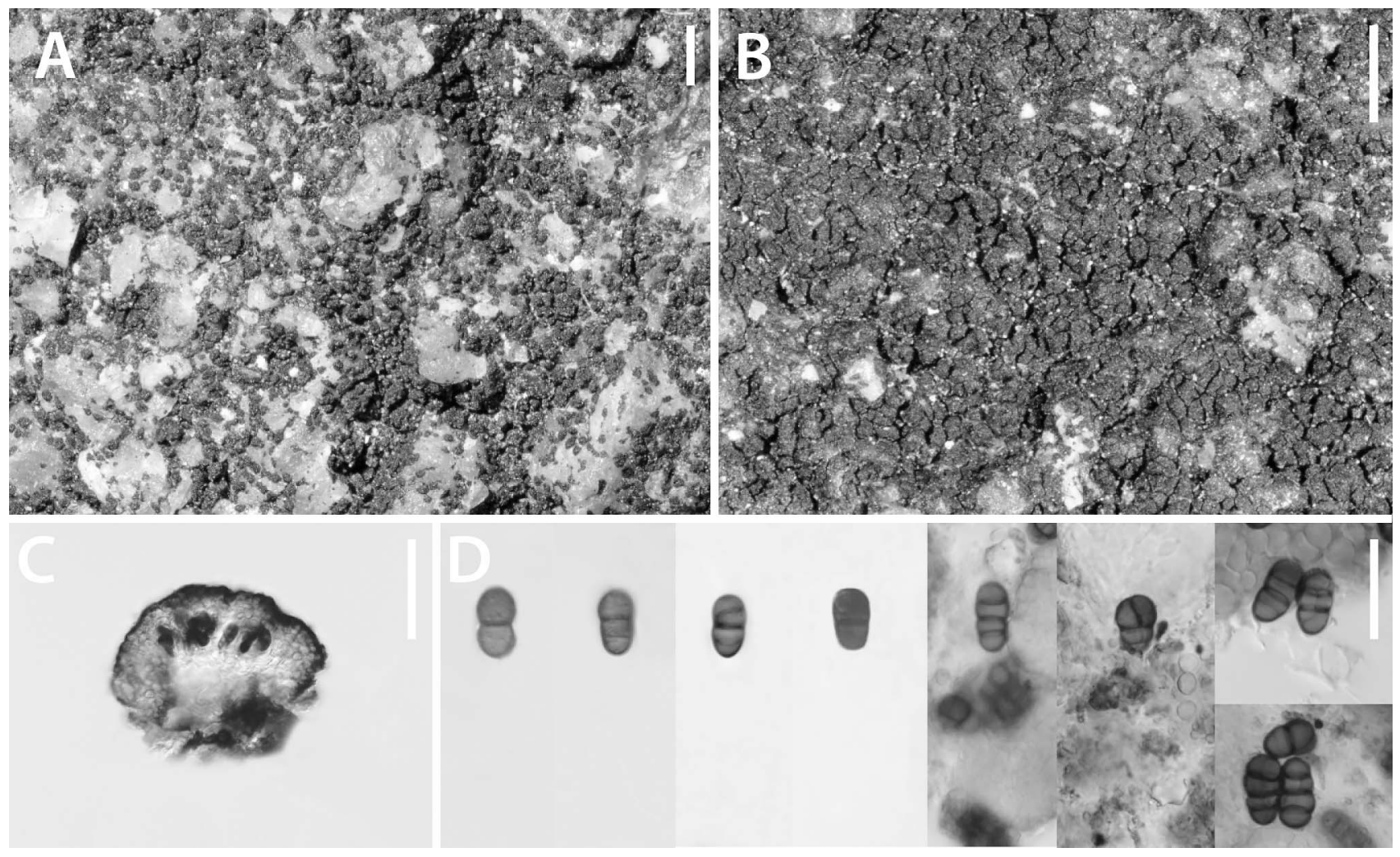

Fig. 5. Lichenothelia umbrophila var. pullata (A, C, Muggia L1323, holotype; B, D, J. Kocourková 8563, topotype). A, B) Thallus and fertile stromata. A. Thin irregular thallus with radiating plurihyphal strands. B. Compact areolate thallus, fertile and sterile stromata mixed. C. Vertical section of fertile stroma with paraplectenchymatous wall. D. 1-3-septate to submuriform mature ascospores. Bars: A, B $=0.5 \mathrm{~mm} ; \mathrm{C}=50 \mu \mathrm{m} ; \mathrm{D}=20 \mu \mathrm{m}$.

were dispersed in Dothideomycetes. Lichenothelia arida also is polyphyletic in nuSSU and paraphyletic in mtSSU, here forming one big, low-supported lineage and leaving the sample L1702 on own basal branch. Lichenothelia calcarea is monophyletic in the mtSSU analyses, whereas it is polyphyletic based on $28 \mathrm{~S}$ and $18 \mathrm{~S}$ data. Lichenothelia convexa is monophyletic based on $28 \mathrm{~S}$ and $18 \mathrm{~S}$ but paraphyletic based on the mt16S data. Lichenothelia umbrophila is monophyletic in $28 \mathrm{~S}$ and paraphyletic in 18S. Monophyletic Lichenothelia clades are never fully supported. The two cultured strains, L1854 and L1855, isolated from the thallus of L. convexa L1609, are recovered basal to Dothideomycetes based on 28S dataset, nested in Lichenotheliales based on $18 \mathrm{~S}$ and basal to Lichenostigmatales based on mt16S. The cultured strains L2186 and L2198, isolated from the thallus of $L$. arida L2161, always group in Capnodiales.
The phylogenetic inference based on the combined dataset (FIG. 6) recovers Lichenothelia calcarea as the only well supported monophyletic taxon. Lichenothelia arida is paraphyletic, again represented by one well supported clade, including six environmental specimens and two cultured strains, and six individual specimens: Four thalli and one cultured strain are closely related to $L$. calcarea, whereas a further cultured strain L2197 is basal to the large lineage including L. convexa, L. umbrophila and Lichenothelia sp. Lichenothelia convexa is paraphyletic and a single cultured strain groups together with L. calcarea specimens. Lichenothelia umbrophila is monophyletic and includes intermixed two samples from Europe (L. umbrophila var. pullata) and two from California. The order Lichenotheliales further includes 11 specimens of different origins (from Muggia et al. [2013] and Ertz et al. [2013]), which remain unknown Lichenothelia species.

Fig. 6. Multilocus phylogenetic inference of Lichenothelia taxa. The ML and Bayesian phylogenetic hypotheses were inferred from the combined dataset of 28S, $18 \mathrm{~S}$ and mt16S. ML and Bayesian topologies corresponded, the ML analysis is shown; Bayesian posterior probabilities ( $\mathrm{PP}>95 \%)$ and ML bootstrap support values $(>70 \%)$ are 


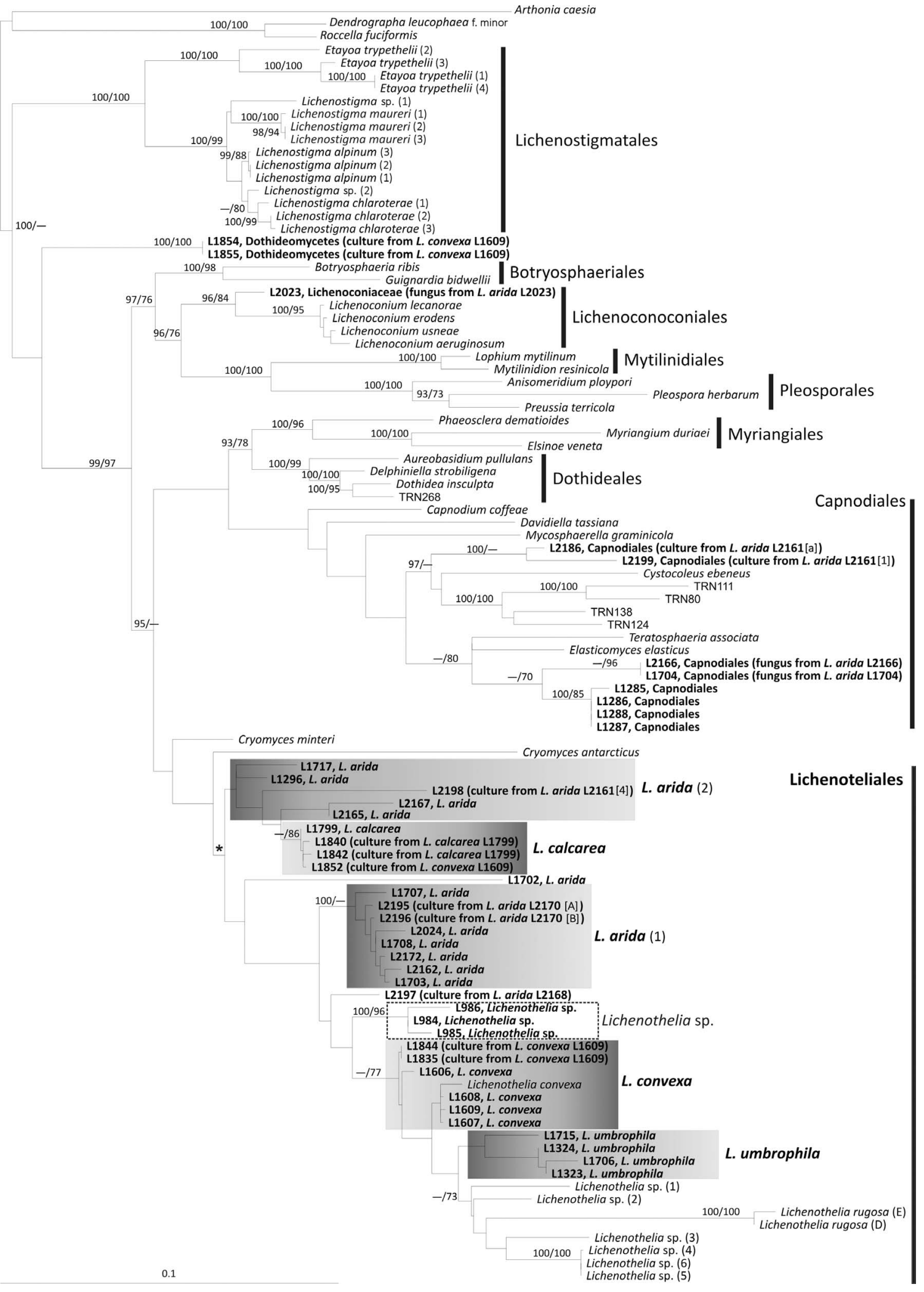

reported above branches (PP/bootstrap value). The clades representing the new Lichenothelia species are highlighted. Samples that were analyzed by the authors are reported in boldface. 

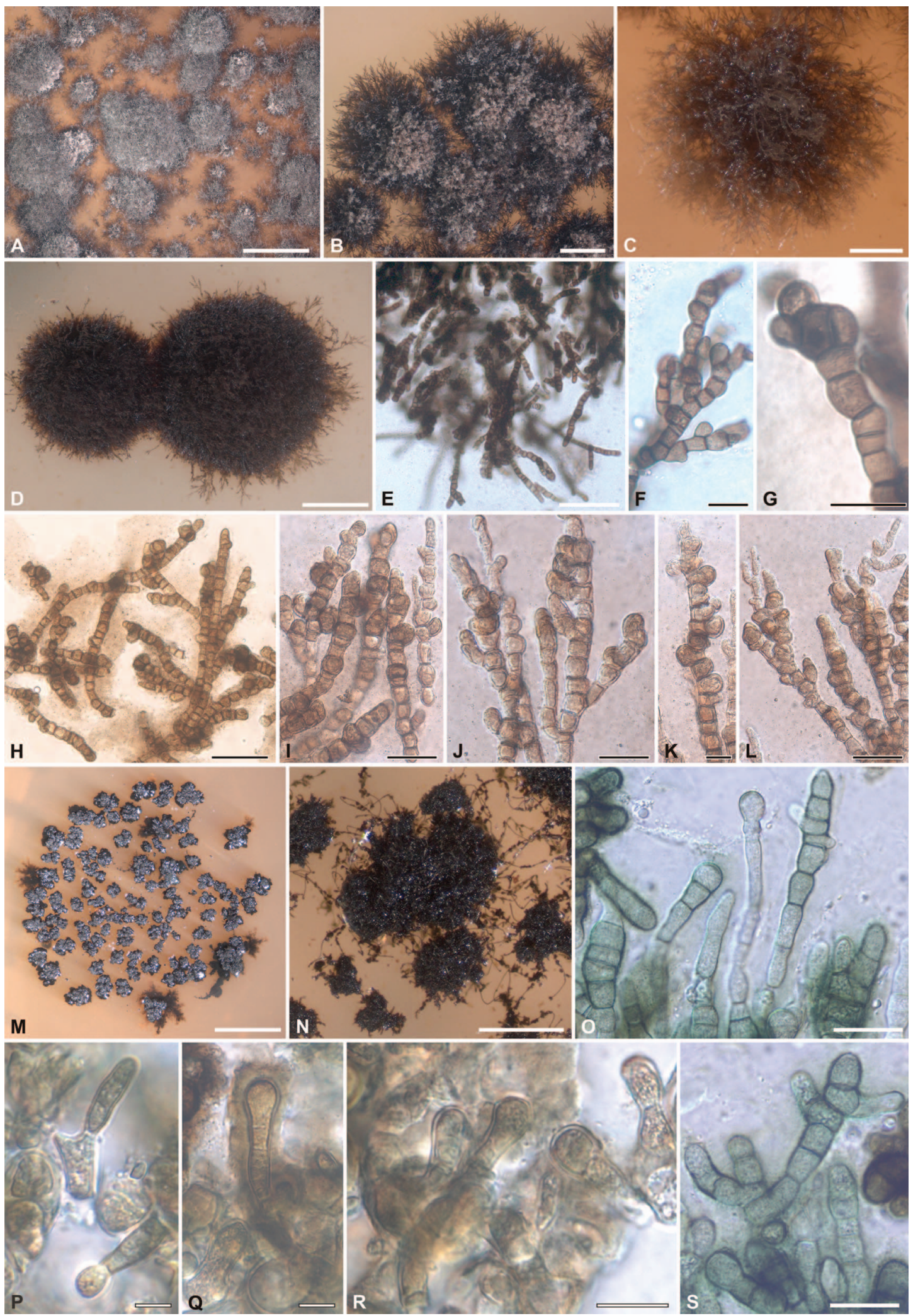

FIG. 7. Habitus of cultured Lichenothelia calcarea and L. convexa and squashed section mounted in water. Cultures are 5 mo old and their phylogenetic position is reported (FIG. 6). A-L. L. calcarea, M-S. L. convexa. A-C. Subcultures L1840 and L1842 of inocula obtained from the original sample L. calcarea L1799. D. Subculture L1852 of inoculum obtained from sample L. convexa L1609. E-L. Morphological structure of the hyphae: The fungal hyphae are melanized and composed by almost isodiametric 
In the multilocus inference the two strains, L1854 and L1855, form a lineage basal to Dothideomycetes whereas the two strains, L2186 and L2199, are recovered in Capnodiales. The non-Lichenothelia fungus amplified from the Lichenothelia specimen L2023 is recovered basal to Lichenoconiales, whereas the other two non-Lichenothelia fungi amplified from $L$. arida thalli, L2166 and L1704, are recovered in Capnodiales, closely related to a lineage of black fungi also isolated from Lichenothelia thalli in Muggia et al. (2013).

\section{TAXONOMY}

Lichenothelia D. Hawksw. Lichenologist 13:142 (1981). MycoBank MB2855

Type species: Lichenothelia scopularia (Nyl.) D. Hawksw.

The genus Lichenothelia is composed of taxa that are saprobes, often receiving nutrition through irrigation or wind. Species also often are associated loosely with algae, and some taxa are possibly algicolous; some species are lichenicolous. The thallus is endolithic or epilithic when saxicolous, episubstratic or endokapylic when lichenicolous, black, dispersed or continuous, areolate or not, rarely effigurate. Lichenothelia species frequently produce black superficial hyphae, branching or not, sometimes connecting scattered stromata. Meristematic growth is frequent. Fertile stromata with one locule are ostiolate with interascal filaments or are multilocular, pseudoparenchymatous throughout the stroma and lack an ostiole, releasing ascospores through decay of stroma wall. The asci are globose to broadly clavate, bitunicate, ascus stain is lacking or sometimes is $\mathrm{K} / \mathrm{I}+$ bluish around the outer wall (but an artifact in some specimens from interascal gel more concentrated around asci) or the apex of the ascus is I+ blue along the edge of endoascus. Asci contain 4-8 spores. The interascal gel is amyloid or not. The ascospores are usually hyaline in early development, becoming golden or pale brown and then darker brown or darker reddish brown, usually ornamented and halonate, one-septate to muriform (this character can be variable within a single species). Ascospores are often released when one-septate and continue to grow outside the ascus, often becoming three-rarely to 10-celled. Pycnidia are rare, about 70 $80 \mu \mathrm{m}$, conidiogenous cells are globose, usually ca. 5.0-6.0 $\mu \mathrm{m}$ diam, indistinct from surrounding vegetative cells. Microconidia are simple, hyaline, short, rod-shaped. Macroconidia, if present, are black and multicelled, globose, usually 8-15 $\mu \mathrm{m}$ wide, often stipitate.

Lichenothelia arida Muggia, Kocourk. \& K. Knudsen, sp. nov.

FIG. 1 MycoBank MB812016.

Typification: USA: CALIFORNIA; Upper Covington Flats, $34^{\circ} 00^{\prime} 51^{\prime \prime} \mathrm{N} 116^{\circ} 18^{\prime} 06^{\prime \prime} \mathrm{W}, 1431 \mathrm{~m}$, on granite boulder under pinyon pine, 21-XI-2011, K. Knudsen 15181 Ė J. Kocourková (holotype UCR-239148). Isotype GZU 00326419.

Etymology: The Latin aridus means dry; the term indicates the dry environment occupied by this species.

Diagnosis: Similar to Lichenothelia calcarea but differing in wider and longer strands of superficial hyphae on non-calcareous substrates.

Thallus saxicolous, black, of small orbicular to unoriented, dispersed or confluent thin patches 1-6 $\mathrm{mm}$ diam, with clustered stromata in central part, surrounded by radial, branched, flat to convex strands up to $130 \mu \mathrm{m}$ long, 30-110 $\mu \mathrm{m}$ wide, of superficial paraplectenchymatous cells 5-10 $\mu \mathrm{m}$ diam, forming 2-3 outer layers of round to angular dark brown cells and hyaline to golden brown internal cells. Well-developed patches without strands or young, small patches with short palmate strands with one central stroma are occasionally seen; thalli can merge, forming patches up to several centimeters across. Stromata ostiolate, unilocular, superficial, round or irregular, constricted at base in stipe up to $110 \mu \mathrm{m}$ high, black, matt, with flat disk and slightly elevated margin, or concave, rough, sometimes umbonate, to $180-450 \mu \mathrm{m}$ diam, 150-270 $\mu \mathrm{m}$ tall; wall paraplectenchymatous, outer cells dark brown, round to angular 5.0-10 $\mu \mathrm{m}$, internal cells larger up to $13 \mu \mathrm{m}$, hyaline to golden brown; center of interascal filaments $1-4 \mu \mathrm{m}$ wide, septate, widened and brownish at apices, up to $6 \mu \mathrm{m}, \mathrm{I}-(\mathrm{dex}-$ trinoid). Asci clavate to subglobose, 4-8-spored, with biseriate ascospores, 50-75 × 15-45 $\mu \mathrm{m}$, asca gel I(dextrinoid), without distinct ascus stain. Ascospores hyaline and one-septate in early ontogeny, often released light brown and one-septate, finely verruculose, halonate, halo $2-5 \mu \mathrm{m}$ thick, $17-18 \times 7-8 \mu \mathrm{m}$, becoming dark reddish brown with 2-3 septa, constricted at medial septum, rarely sub-muriform with up to eight cells, (17-)20-22.7-25.5(-28) × (7-)10$11.6-13 \quad(-13.5) \quad \mu \mathrm{m} \quad(\mathrm{n}=25), \mathrm{l} / \mathrm{b}=(1.7-) 1.8-1.93$

cells; apical and lateral meristematic growth is frequently observed and originate ramifications and lateral hyphae. M, N. Subcultures L1835 and L1840 of the original sample L. convexa L1609. O-S. Melanized hyphae are observed, apical and lateral meristematic growth is frequent, with the apex of hyphae distinctly dividing by septation ( $\mathrm{P}-\mathrm{R})$. Bars: A, $M=2 \mathrm{~mm} ; \mathrm{B}, \mathrm{D}, \mathrm{E}, \mathrm{N}=0.5 \mathrm{~mm}$; $=0.25 \mathrm{~mm} ; \mathrm{F}, \mathrm{H}=50 \mu \mathrm{m} ; \mathrm{G}, \mathrm{I}, \mathrm{J}, \mathrm{L}, \mathrm{O}, \mathrm{R}, \mathrm{S}=20 \mu \mathrm{m} ; \mathrm{K}, \mathrm{P}, \mathrm{Q}=10 \mu \mathrm{m}$. 

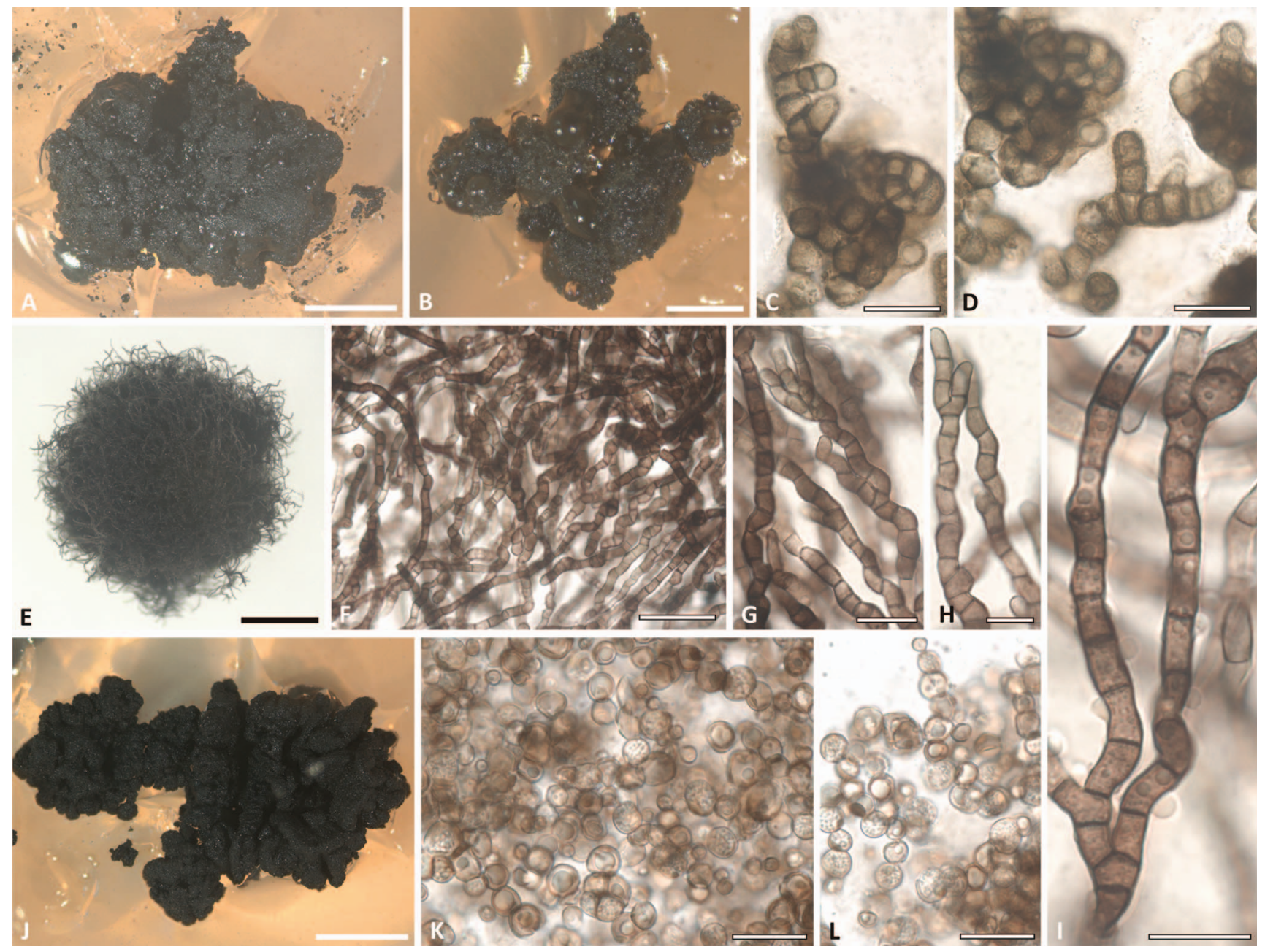

FIG. 8. Habitus of cultured Lichenothelia arida in squashed section mounted in water. The phylogenetic position of the original samples and of the cultures is reported in the analyses (FIG. 6). A-D. Five mo old inocula L2195 and L2196 from the original samples L. arida L2170, melanized hyphae with lateral "budding" (C, D). E-I. Three mo old inoculum L2197 of samples L. arida L2168; melanized hyphae are composed by rectangular cell and are frequently branched (F-I). J-L. Inoculum L2198 of original sample $L$. arida L2161, the cultured colony is composed by melanized, globose, yeast-like cells that do not structure into hyphae. Bars: J $=4 \mathrm{~mm} ; \mathrm{A}, \mathrm{M}=2 \mathrm{~mm} ; \mathrm{B}, \mathrm{E}=0.5 \mathrm{~mm} ; \mathrm{F}=40 \mu \mathrm{m} ; \mathrm{C}, \mathrm{D}, \mathrm{G}, \mathrm{I}, \mathrm{K}, \mathrm{L}=20 \mu \mathrm{m} ; \mathrm{H}=10 \mu \mathrm{m}$.

-2.1(-2.3). Pycnidia rare, about $70-80 \mu \mathrm{m}$, conidiogenous cells globose, indistinct from surrounding vegetative cells, microconidia simple, hyaline $5-7 \times 1$, $(\mathrm{n}=20)$. Cultures have a black mycelium, forming globose colonies with isodiametric cells, forming dense agglomerates that seldom branch or form a loose mycelium with elongated cells and frequent branching.

Substrate and ecology. On basalt, gneiss, granite and quartz, usually in full sun, seldom associated with crustose lichens, or rarely growing in the shade of creosote bush, junipers, pines, or oaks, and then often growing intermixed with L. umbrophila.

Distribution. Mojave and Sonoran deserts in southern California at $10-1576 \mathrm{~m}$. It is abundant in the California deserts as a pioneer fungus on rocks in full sun, frequently on slopes and in seasonal desert washes.
Other material examined: USA. CALIFORNIA: Riverside County, Joshua Tree National Park: Hexie Mountains, $33^{\circ} 57^{\prime} 22.5^{\prime \prime} \mathrm{N} \quad 116^{\circ} 00^{\prime} 48.9^{\prime \prime} \mathrm{W}, 1038 \mathrm{~m}$, on quartz, 20-XI-2012, K. Knudsen 15158.1 w. J. Kocourková (UCR); Hexie Mountains, edge of Pleasant Valley, $33^{\circ} 55^{\prime} 21.3^{\prime \prime} \mathrm{N} 116^{\circ} 02^{\prime} 35.2^{\prime \prime} \mathrm{W}, 995 \mathrm{~m}$, on gneiss and quartz, 09-XII-2013, K. Knudsen 16329 w. M. Harding $\mathcal{E}^{\mathcal{V}} \mathrm{J}$. Heintz (UCR, with L. umbrophila); Lost Horse Mountains, $33^{\circ} 57^{\prime} 13.6^{\prime \prime} \mathrm{N} 116^{\circ} 09^{\prime} 12.2^{\prime \prime} \mathrm{W}, 1502 \mathrm{~m}$, on basalt rocks embedded in soil between screes, 26-XII2010, K. Knudsen 13364 (UCR); Malapai Hill, $33^{\circ} 56^{\prime} 19^{\prime \prime} \mathrm{N} 116^{\circ} 05^{\prime} 06.1^{\prime \prime} \mathrm{W}, 1176 \mathrm{~m}$, on basalt, 02-XII2010, K. Knudsen 12648 (UCR); Little San Bernardino Mountains, Pushwalla Trail, on granite boulders along wash, 33 $53^{\circ} 08^{\prime \prime} \mathrm{N} 116^{\circ} 06^{\prime} 25.7^{\prime \prime} \mathrm{W}, 1347 \mathrm{~m}, 17-\mathrm{XI}-2011$, K. Knudsen 14252.1 w. J. Kocourková (UCR); Little San 
Bernardino Mountains, $33^{\circ} 50^{\prime} 01^{\prime \prime} \mathrm{N} \quad 116^{\circ} 04^{\prime} 28^{\prime \prime} \mathrm{W}$, $1080 \mathrm{~m}$, on granite rubble, 15-XI-2011, K. Knudsen 14226 w. J. Kocourková (UCR); Pinto Basin, 33 51'51" $\mathrm{N} 115^{\circ} 37^{\prime} 09.8^{\prime \prime} \mathrm{W}, 644 \mathrm{~m}$, on small rocks along shallow wash, 06-XI-2012, J. Kocourková 8576 (Hb. JK \& KK); Ryan Mountain, $33^{\circ} 59^{\prime} 33.5^{\prime \prime} \mathrm{N} 116^{\circ} 08^{\prime} 00^{\prime \prime} \mathrm{W}, 1578 \mathrm{~m}$, on granite under stunted juniper, 21-XI-2011, K. Knudsen 14399 Ẽ J. Kocourková 14399 (UCR ); Wilson Canyon, along wash, 33 $57^{\prime} 44.6^{\prime \prime} \mathrm{N} 115^{\circ} 59^{\prime} 19^{\prime \prime} \mathrm{W}, 965 \mathrm{~m}$ on granite, 29-XII-2010, K. Knudsen 13461 (UCR ). San Bernardino County: 49 Palms Canyon, $34^{\circ} 06^{\prime} 22.7^{\prime \prime} \mathrm{N} \quad 116^{\circ} 06^{\prime} 18.1^{\prime \prime} \mathrm{W}, 844 \mathrm{~m}$, on granite beneath creosote bush with much detritus, 29-XII2010, K. Knudsen 13472.1 (UCR); desert near north entrance, $34^{\circ} 05^{\prime} 45^{\prime \prime} \mathrm{N} 116^{\circ} 02^{\prime} 20^{\prime \prime}, 767 \mathrm{~m}$, on scattered rocks along base of shallow wash, 13-IV-2011, K. Knudsen et al.13534 (UCR); Coxcomb Mountains, at west end, $33^{\circ} 49^{\prime} 30.7^{\prime \prime} \mathrm{N} 115^{\circ} 16^{\prime} 23.6^{\prime \prime} \mathrm{W}, 159 \mathrm{~m}$, creosote bush, on silicate rock along shallow wash, K. Knudsen 14427 w. M. Michalová Ẽ M. Harding (UCR).

Cultures: LMCC0496 (MUT 568), LMCC0497 (MUT 5686).

Notes: Lichenothelia arida is common throughout the Sonoran and Mojave deserts in Joshua Tree National Park on basalt, gneiss, granite and quartz. Thalli, mostly orbicular with spidery superficial hyphae, cover exposed, relatively smooth rock surfaces and form an open, dispersed pattern, leaving the substrate visible. On granite rocks with rough surfaces, the superficial hyphae are poorly developed and the stromata are reduced and less stipitate than in the samples from basalt or gneiss. Lichenothelia arida generally occurs as a pioneer species on exposed rocks in full sun on slopes and in washes, where it is periodically flushed with water or collects aeolian particles. It is rarely found under trees or shrubs, where it often grows intermixed with L. umbrophila. No specimens were collected in alkaline seepage tracks, common on granite outcrops, a favored microhabitat of Lichinaceae and relic calcareous species from earlier geological periods.

The two specimens, Knudsen 14427 (UCR) and Knudsen 16329 (UCR), have distinctly pulvinate and stipitate stromata and lack thin radiating superficial plurihyphal strands and the orbicular thallus pattern. The stromata were subtended by distinct lobes to $160 \mu \mathrm{m}$ wide, often with a lower surface. This phenotype occurs on both smooth and rough rock surfaces, also in the co-presence of thalli with orbicular pattern and spidery superficial hyphae. It may represent an occasional phenotype not induced by environmental conditions but likely correlated to the genetic diversity. These specimens indeed are those not included in the monophyletic clade formed by the core group of
L. arida. Pycnidia were more frequent in this morphotype without distinct plurihyphal strands.

Lichenothelia aridia is similar to L. calcarea in thallus morphology, stipitate stromata, ascospore size, I- ascal gel and conidia length. Lichenothelia calcarea is found, however, only on limestone and L. arida on basalt, granite, gneiss and quartz. Lichenothelia arida also has wider and longer strands of superficial hyphae than L. calcarea. Lichenothelia scopularia, the type species of the genus, and L. metzleri both are saxicolous and have interascal filaments with an I- interascal gel but differ especially in the thallus, which forms areoles or plates in the center with adnate fertile stromata. Lichenothelia antarctica Øvstedal has interascal filaments and I- ascal gel but has an areolate and isidioid thallus, non-stipitate fertile stromata and larger ascospores up to $40 \mu \mathrm{m}$ long (Øvstedal and Smith 2001). In our phylogenetic analysis Lichenothelia arida is a paraphyletic taxon that splits into one well-supported clade and five paraphyletic samples on own branches basal in Lichenotheliaceae.

Lichenothelia calcarea Henssen, Bibl Lichenol 25:259 (1987)

FIG. 2 MycoBank MB130695.

Typification: USA. CALIFORNIA: Inyo County, Darwin Wash, on limestone, $1200 \mathrm{~m}, 1981$, C. Bratt 2140a (holotype MB, n.v.). Isotypes SBBG! H!; isotype Boise State University n.v.).

Thallus saxicolous, black, orbicular, of dispersed to confluent patches $1-5 \mathrm{~mm}$ diam, with clustered stromata in central part, surrounded by radial, net forming, flat strands up to $90 \mu \mathrm{m}$ long, 20-50 $\mu \mathrm{m}$ wide, of dark superficial hyphae of cells 4-7 $\mu \mathrm{m}$ diam, only 23 cells thick. Stromata ostiolate, unilocular, black, round, widely conical with short stipe, disk flat or indented, smooth to rough, sometimes umbonate, finely ostiolate, to $370 \mu \mathrm{m}$ diam, in section outer cells 5-10 $\mu \mathrm{m}$ dark brown, inner cells hyaline, center with branching interascal filaments of cells $2-5 \mu \mathrm{m}$ diam, interascal gel I- (dextrinoid). Asci clavate to subglobose, usually six-spored, ascospores biseriate, 60-70 $\times 25-35 \mu \mathrm{m}$, without distinct ascus stain. Ascospores hyaline and one-septate only in early ontogeny, turning golden and soon becoming dark red-brown, smooth, most of mature ascospores one-septate, constricted at septum, with halo $2-5(-8) \mu \mathrm{m}$ wide; rare three-septate to muriform ascospores with up to seven cells within or outside the ascus, (20.3-)21.5-23.8 $-26.0(-27.0) \times(9.6-) 11.3-13.5-15.7(-16.8) \mu \mathrm{m}$ $(\mathrm{n}=20), \quad \mathrm{l} / \mathrm{b}=(1.4-) 1.6-1.9-2.1(-2.8)$. Pycnidia not seen in the analyzed specimens: according to Henssen (1987) about 70-80 $\mu \mathrm{m}$ diam, conidia simple, hyaline $4.5-7 \times 1 \mu \mathrm{m}$, conidiogenous cells not described. Cultures commonly produce multiple cells 
forming at the apex of hyphae that are responsible for the meristematic growth and the conspicuous branching; cells are slightly rectangular, either elongate or seeming compressed, with thick wall; only the dividing cells are isodiametric.

Substrate and ecology: It is calciphile, on hard limestone, rare pioneer in washes and forming well-developed communities under junipers and pinyon pines.

Distribution: Mojave Desert (San Bernardino and Inyo counties, California, USA).

Other material examined: USA. CALIFORNIA: San Bernardino County, Clark Mountains, Mojave Natural Preserve: on piedmont slope, $35^{\circ} 30^{\prime} 0^{\prime \prime} \mathrm{N} / 115^{\circ} 40^{\prime} 58^{\prime \prime} \mathrm{W}$, $1117 \mathrm{~m}$, on hard limestone rocks along shallow seasonal wash, 17-VI-2009, K. Knudsen 11443 E $11444 w$. N. Pietrasiak (FH, NY, UCR); Ridge below Clyde Peak, $35^{\circ} 30^{\prime} 37^{\prime \prime} \mathrm{N} / 115^{\circ} 36^{\prime} 39^{\prime \prime} \mathrm{W}, 1772 \mathrm{~m}, 10-\mathrm{X}-2009$, colony beneath pinyon pine on hard limestone, K. Knudsen 11749 w. N. Pietrasiak (UCR), beneath stunted junipers, K. Knudsen 11741 w. N. Pietrasiak (UCR).

Cultures: LMCC0065 (MUT 5685), LMCC0484 (MUT 5684), LMCC0498 (MUT 5683).

Notes: Lichenothelia calcarea occurs in the northern and eastern Mojave Desert on limestone, scattered in washes as a pioneer and in well-developed colonies under junipers and pinyon pines. It was not found in Joshua Tree National Park, where no limestone deposits are present. None of the three other taxa (L. arida, L. convexa, L. umbrophila) collected at Joshua Tree National Park on granite, gneiss or basalt were found on limestone in the Mojave Desert. The holotype of L. calcarea was collected in Darwin Wash in Inyo County by Charis Bratt together with the holotype of L. intermixta Henssen (Henssen 1987). For this study Lichenothelia calcarea from the Clark Mountains in San Bernardino County was studied from UCR. It was rare on hard limestone rocks in washes on the piedmont as a pioneer. On the slopes beneath Clyde Peak, at $1772 \mathrm{~m}$, L. calcarea was abundant in the permanent shade of centuries-old stunted junipers and pinyon pines (Knudsen 11741 E 11749 , UCR). Beneath the junipers and contorted pines there are piles of detritus that soak up water during the rare storms and ooze a brown "tea"; this wets $L$. calcarea and supplies a saprobic feast (see further discussion under L. umbrophila). The slopes are swept with aeolian particles by fierce desert winds that supply added nutrition to these thick colonies.

Henssen (1987) described the ascospores as being one-septate, although we observed ascospores having up to four septa and becoming muriform even in the isotype (SBBG!). Some fertile stroma may contain only muriform ascospores. Lichenothelia calcarea is morphologically and anatomically similar to $L$. arida in ascospore size, stipitate fertile stromata, I- interascal gel and in conidia length. Lichenothelia calcarea differs, however, from $L$. arida in producing net-forming superficial strands, which are shorter and thinner. Lichenothelia calcarea is restricted to limestone, while $L$. arida was collected on granites, gneiss and basalt. Lichenothelia scopularia, the type species of the genus, and $L$. metzleri have interascal filaments with an I-interascal gel but differ especially in the thallus morphology, forming areoles or plates in the center with adnate fertile stromata. Lichenothelia antarctica Øvstedal has interascal filaments and I - interascal gel but has an areolate and isidioid thallus, non-stipitate fertile stroma and larger ascospores up to $40 \mu \mathrm{m}$ long (Øvstedal and Lewis Smith 2001).

Lichenothelia convexa Henssen, Bibl. Lichenol. 25:259 (1987) MycoBank MB130694

Typification: GERMANY. Hessen. Kr. Marburg, Wollenberg, on quartzite, 1980, Henssen s.n. (holotype MB n.v.). Syn. Nov. Lichenostigma saxicola K. Knudsen \& Kocourk., Bryologist 113:230 (2008). TYPE: USA, California, San Diego County, Henderson Canyon, Anza Borrego State Park, north-facing slope, 331' $35^{\prime \prime} \mathrm{N} 116^{\circ} 25^{\prime} 21^{\prime \prime} \mathrm{W}, 427 \mathrm{~m}$, on granite and parasitic on apothecia of Polysporina simplex, 15-III- 2008, K. Knudsen 9242 w Tom Chester Eॄ Wayne P. Armstrong (Holotype: UCR-190945; isotype: PRM 859188).

Thallus saxicolous and lichenicolous, black, dispersed, fertile or sterile stromata, sometimes congregated; meristematic outgrowths of various sizes and shapes produced from surface of stromata. Stromata non-ostiolate but eventually opening by wall decay to disperse ascospores, multilocular, irregularly rounded, convex to somewhat flat, mostly $100-200 \times 90-120$ $(-150) \mu \mathrm{m}$, some becoming as wide as $400 \mu \mathrm{m}$ across, infrequently producing 1-3 superficial hyphae, "stolons" sensu Henssen (1987), up to $1 \mathrm{~mm}$ long but often shorter, one cell wide, cells various sizes, many 4-6 $\times 4-6 \mu \mathrm{m}$, often forming new stromata at tip of stolon, sometimes three stromata appearing linked in row. Stromata paraplectenchymatous throughout, with round to angular cells mostly 4-5 $\mu \mathrm{m}$ diam, external cells brown, internal cells hyaline to light brown, I(dextrinoid), often sterile. Asci in locules in the stromata, bitunicate, broadly saccate to clavate, 20-30 $(-35) \times 10-20 \mu \mathrm{m}$, mostly eight-spored, without distinct ascus stain. Interascal gel I+ blue, sometimes weak, reaction not observed when stromata sterile or asci few and immature or overmature. Ascospores hyaline to light brown when young, becoming darker brown, ellipsoid to broadly ellipsoid, faintly ornamented, halonate at least when young, cells not equal in size, 1-4 septate, sometimes becoming submuriform, $(10.0-)$ 10.5-10.8-11.5 (-12.0) × (5.0-)6.0-6.1-6.5 $\mu \mathrm{m}$ $(\mathrm{n}=20) ; \mathrm{l} / \mathrm{b}=(1.5-) 1.7-1.8-1.9(-2.1)$. Few larger, 
over-mature submuriform ascospores were seen, $14 \times 6-6.5 \mu \mathrm{m}$, but were excluded from average measurements (Henssen [1987] ascospore measurements are 11-14 × 5.5-6.5 $\mu \mathrm{m})$. Pycnidia and microconidia not observed; macroconidia rare, globose, non-stipitate, 10-15(-20) $\mu \mathrm{m}$. Cultures form a compact mycelium, with elongate hyphal cells sometimes joined by thicker, more isodiametric cells.

Distribution, substrate and ecology: It occurs on basalt, granite, gneiss, shale, serpentine and quartzite in North America and Europe, in a wide variety of habitats from coastal to desert and montane; rarely found solitary on bare rock, almost always associated and parasitic on lichens. It occasionally occurs as a parasite on lichens in biotic soil crusts.

Other material examined (out of more than 50 collections): CZECH REPUBLIC. Eastern Bohemia, Krkonoše National Park, Krkonoše Mountains $50^{\circ} 43^{\prime} 20^{\prime \prime} \mathrm{N}$, $15^{\circ} 42^{\prime} 03^{\prime \prime} \mathrm{E}, 1426 \mathrm{~m}$, on granite outcrop and Lecidea spp., 10-X-2010, K. Knudsen 12560 w. J. Kocourková (Hb. JK \& KK). Central Bohemia, Praha District, Pitkovice, Pitkovická stráň, $50^{\circ} 1^{\prime} 26^{\prime \prime} \mathrm{N}, 14^{\circ} 34^{\prime} 21^{\prime \prime} \mathrm{E}, 276 \mathrm{~m}$, on shale and Rinodina aspersa, 21-IX-2010, J. Kocourková 7744 (Hb. JK \& KK), on shale and Acarospora gallica, K. Knudsen 12452 (BM, GZU, Hb. JK \& KK); Nová Ves, Prokopské Valley, Hemrovy rocks, $50^{\circ} 2^{\prime} 34.88^{\prime \prime} \mathrm{N}$, $14^{\circ} 21^{\prime} 11.613^{\prime \prime} \mathrm{E}, 265 \mathrm{~m}$, on west-facing slope above road, on diabase and Acarospora fuscata, 07-VI-2010, J. Kocourková 7404 (Hb. JK \& KK); GERMANY. Hessen, Kreis Marburg/Biedenkopf, TK 25: 5117 Buchenau, Wollenberg, Wichtelhäuser, Hohler Stein, 385 m, on quartzite, 13-VIII-1989, H.T. Lumbsch E E. Mietzsch 6948 (B, topotype); Harz. Selketal, Meiseberg, 03-VI1990, H.T. Lumbsch (B). USA. CALIFORNIA: Los Angeles County, Malibu State Park, Castro Crest $34^{\circ} 4^{\prime} 8^{\prime \prime} \mathrm{N}, 118^{\circ} 45^{\prime} 8^{\prime \prime} \mathrm{W}, 625 \mathrm{~m}$, on Myriospora hassei, 24-X-2004, K. Knudsen 1880.2 w. Owe-Larsson (UCR); Riverside County, Joshua Tree National Park: along wash in open desert under Acacia on unknown lichen, $33^{\circ} 56^{\prime} 20.3^{\prime \prime} \mathrm{N}, 116^{\circ} 4^{\prime} 58.7^{\prime \prime} \mathrm{W}, 1163 \mathrm{~m}, 02-\mathrm{XII}-2010$, Knudsen 12564 (UCR); Ryan Mountain, 33 $59^{\prime} 12^{\prime \prime} \mathrm{N}$, $116^{\circ} 8^{\prime} 4.2^{\prime \prime} \mathrm{W}$, on gneiss and Buellia dispersa, 06-XII2010, K. Knudsen 12824 (UCR); behind Squaw Tank $33^{\circ} 55^{\prime} 48.4^{\prime \prime} \mathrm{N}, 116^{\circ} 4^{\prime} 26.2^{\prime \prime} \mathrm{W}, 1080 \mathrm{~m}$, on porous monzogranite (algicolous?), 04-XII-2010, K. Knudsen 12742 (UCR). San Bernardino County, Joshua Tree National Park, Queen Mountain, $34^{\circ} 3^{\prime} 9.9^{\prime \prime} \mathrm{N}$, $116^{\circ} 6^{\prime} 9.4^{\prime \prime} \mathrm{W}, 1627 \mathrm{~m}$, on Aspicilia species, 05-X-2011, K. Knudsen 13726 w. M. Harding (UCR); San Bernardino Mountains, San Bernardino National Forest, the Pinnacles, $34^{\circ} 17^{\prime} 49.4^{\prime \prime} \mathrm{N}, 117^{\circ} 12^{\prime} 51.6^{\prime \prime} \mathrm{W}, 1451 \mathrm{~m}$, 13-XII-2013, on Sarcogyne mitziae and Aspicilia, K. Knudsen 16362 w. M. Crawford E् A. Simmons (UCR).

Cultured strains: LMCC0061 (MUT 5682), LMCC0499 (MUT 5681)
Notes: Lichenothelia convexa originally was described from Germany. Henssen (1987) also reported it from Sweden and North America (California, Colorado, Washington). In our study we used a topotype collected by T. Lumbsch, her student, from the type locality, because Marburg (MB) was unable to supply the holotype or any other material for this study. It is apparently a widespread but under-collected species in Europe (Muggia et al. 2013) and North America and it is expected to occur also in Asia. In southern California it is common in both coastal habitats as well as montane and desert habitats at different elevations (Henssen 1987, Kocourková and Knudsen 2011). It is found associated usually with saxicolous lichens, growing on granite, quartzite, basalt, gneiss, shale and serpentine. No specimens have been identified from calcareous substrates. Lichenothelia convexa often is associated with algae on rock surfaces and in rock crevices. It is lichenicolous, not host specific, and was collected on thalli and apothecia of a wide variety of saxicolous species (Knudsen and Kocourková 2008, Kocourková and Knudsen 2011). Lichenothelia convexa usually covers the host with black stroma. Some hosts appear healthy otherwise, others seem to become sterile. The thallus of some host species, like Aspicilia glaucopsina (Nyl. ex Hasse) Hue, for instance, develops white patches, probably due to the death of the photobionts and eventually are destroyed. Its strong parasitic behavior may endanger the long-term survival of some rare saxicolous and terricolous lichen species, such as Sarcogyne mitziae K. Knudsen, Kocourk. \& McCune. Sarcogyne mitziae is a recently described species, which was considered to be a Pleistocene relic in the southwestern Mojave Desert in Joshua Tree National Park (Knudsen et al. 2014). In southern California $S$. mitziae is currently known from three sites and every collected specimen was heavily infected with $L$. convexa, which probably has hampered its long-term survival in a changed climate. L. convexa is probably the most common lichenicolous fungus in southern California (Kocourková et al. 2012), according to our experience.

The species originally was described as having threeto four-celled ascospores; although, in the specimens examined, single-septate ascospores were most common and ascospores with three or more cells were rare. The usually amyloid ascal gel can test I- if present in low concentrations. Lichenostigma saxicola $\mathrm{K}$. Knudsen \& Kocourk. was described from southern California and was distinguished from $L$. convexa based on the I- reaction and prevalence of one-septate ascospores (Knudsen and Kocourková 2010). Lichenostigma saxicola is recognized here as a synonym of $L$. convexa. 
Lichenothelia umbrophila Muggia, Kocourk. \& K. Knudsen, sp. nov. FIG. 4. MycoBank MB812019

Typification: USA. CALIFORNIA; Riverside County: North-facing side of outside wall of Hidden Valley tors: in sight of Park Blvd., $34^{\circ} 01^{\prime} 14.8^{\prime \prime} \mathrm{N}$, $116^{\circ} 10^{\prime} 29.4^{\prime \prime} \mathrm{W}, 1244 \mathrm{~m}$, on gneiss in narrow canyon below pinyon pine, 09-XII-2013, K. Knudsen $16331 \mathrm{w}$. M. Harding $\mathcal{E}^{2}$ J. Heintz (holotype UCR-246242, Hb. JK \& KK, isotype);

Etymology: The name is based on its ecology, growing in the permanent shade of trees.

Diagnosis: Similar to Lichenothelia prolifera but differing especially in having wider ascospores in eightspored asci.

Thallus saxicolous, black, of small, usually irregular, dense patches 1-3 mm diam, central part with clustered stromata and sterile round or angular areoles later developing in fertile stromata, surrounded with radial or unoriented, flat to slightly convex, segmented, branching strands of superficial hyphae, of 1-10 cells across, 10-50 $\mu \mathrm{m}$ wide; thallus patches often fuse in large nets forming dark areas several meters wide. Stromata ostiolate, unilocular, black, round to oval, sometimes angular when compressed from sides in dense groups, sessile to conical, flat to convex, smooth, partly shiny, mostly $0.2-0.5 \mathrm{~mm}$ diam, 250-300 $\mu \mathrm{m}$ high, paraplectenchymatous, outer cells dark brown, round to angular 5.0-10 $\mu \mathrm{m}$, internal cells same size, pale brown, center of interascal filaments embedded in gel and hardly visible, $5-8 \mu \mathrm{m}$ wide, interascal gel I + blue, amyloid. Asci subglobose to globose, eightspored, ascospores biseriate, 50-76 × 25-50 $\mu \mathrm{m}$, without distinct ascus stain. Ascospores hyaline when young and one-septate in early ontogeny, halo 2-4 um wide but soon dissolving, often released at ca. $20 \times 8 \mu \mathrm{m}$, mature spores within or outside of asci becoming brown, finely verruculose, three-septate and eventually muriform with usually eight cells, constricted at center septum, (18.5-)21.0-23.5-25.5(-27.0) $\times(9.5-)$ 11.0-12.4-14.0(-14.5) $\mu \mathrm{m} \quad(\mathrm{n}=20), \mathrm{l} / \mathrm{b}=(1.7-) 1.8$ -1.87-2.0. Pycnidia about 70-80 $\mu \mathrm{m}$, conidia simple, hyaline, $4-5 \times 1 \mu \mathrm{m}(\mathrm{n}=20)$. Conidiogenous cells globose, ca. 5.0-10.0 $\mu \mathrm{m}$ diam, indistinct from surrounding vegetative cells. Not isolated in culture.

Distribution, substrate and ecology: It occurs on gneiss and granite, under pinyon pines, junipers or oaks in permanent shade, rarely under creosote bushes, forming dense black communities covering several meters, above $1200 \mathrm{~m}$, in North America (Mojave and Sonoran deserts, Joshua Tree National Park).

Other material examined: USA. CALIFORNIA: Riverside County, Joshua Tree National Park: Little San Bernardino Mountains, Berdoo Canyon, 33 $50^{\prime} 01.7^{\prime \prime} \mathrm{N}$, $116^{\circ} 04^{\prime} 28.7^{\prime \prime} \mathrm{W}, 1080 \mathrm{~m}$, on granite under creosote bush, 15-XI-2011, K. Knudsen 14214 Ẽ J. Kocourková (UCR); Hexie Mountains, edge of Pleasant Valley, $33^{\circ} 55^{\prime} 21.3^{\prime \prime} \mathrm{N}, 116^{\circ} 02^{\prime} 35.2^{\prime \prime} \mathrm{W}, 995 \mathrm{~m}$, on gneiss and quartz, 09-XII-2013, K. Knudsen 16329 (UCR, together with L. arida); Pine City, $34^{\circ} 02^{\prime} 15.4^{\prime \prime} \mathrm{N}, 116^{\circ} 04^{\prime} 28.3^{\prime \prime}$ W, $1374 \mathrm{~m}$, along wash on granite beneath old juniper, 07-X-2011, K. Knudsen 13766 (UCR); Upper Covington Flats, $34^{\circ} 00^{\prime} 51^{\prime \prime} \mathrm{N}, 116^{\circ} 18^{\prime} 08^{\prime \prime} \mathrm{W}, 1426 \mathrm{~m}$, on granite boulder under old juniper in canyon bottom, 09-XI2011, K. Knudsen 14037 Ẽ J. Kocourková (UCR); Upper Juniper Flats, $33^{\circ} 56^{\prime} 00.4^{\prime \prime} \mathrm{N}, 116^{\circ} 10^{\prime} 34.3^{\prime \prime} \mathrm{W}, 1465 \mathrm{~m}$, on granite under oak, 20-XI-2011, K. Knudsen 14342 Ẽ J. Kocourková (UCR); Smith Water Canyon, 34 01' $46.6^{\prime \prime} \mathrm{N}, 116^{\circ} 16^{\prime} 44.9^{\prime \prime} \mathrm{W}, 1279 \mathrm{~m}$, under willows, on granite boulders flushed with water in winter, 13-XII-2010, K. Knudsen 13041 (UCR).

Notes: The rock surfaces often become covered by the convergent superficial hyphae of L. umbrophila, growing in the permanent shade of trees hundreds of years old in Joshua Tree National Park. Lichenothelia umbrophila is associated with free-living algae. It appears to be principally nourished by the saprobic infusions of rain-soaked duff-like L. calcarea as well as Aeolian particles trapped in the dense net of superficial hyphae. When the trees die the permanent shade of the canopy disappears and L. umbrophila is invaded by saxicolous lichens that thrive in the sunlight. The communities formed by L. umbrophila slowly disappear and are succeeded by lichens. Occasionally L. umbrophila was observed to be lichenicolous in these conditions.

Lichenothelia umbrophila is distinguished from L. arida especially by its dense, black thallus widely spreading on the rock surface, and by the I+ blue interascal gel. The only other species with amyloid interascal gel and interascal filaments is Lichenothelia prolifera Henssen, described from Australia (Henssen 1987). Lichenothelia prolifera forms narrower septate to submuriform ascospores than L. umbrophila $(18-22 \times 8-10.5$ vs. $21-25 \times$ 11-14 $\mu \mathrm{m})$ and has four-spored asci.

Lichenothelia umbrophila var. pullata Muggia, Kocourk. \& K. Knudsen, sp. nov. FIG. 5 MycoBank MB812017

Typification: CZECH REPUBLIC: SOUTHERN MORAVIA; Znojmo District, Moravský Krumlov, hill with chapel of Sv. Florián east of the town, $49^{\circ} 2^{\prime} 51.42^{\prime \prime} \mathrm{N}, 16^{\circ} 19^{\prime} 11.12^{\prime \prime} \mathrm{E}, 305 \mathrm{~m}$, on west-facing slope with conglomerate (siliceous-calcareous) rocks, 01-IV-2011, J. Kocourková Ẽ L. Muggia L1323 (holotype GZU 000326420).

Etymology: The adjective "pullatus" means clothed in black, which is how this Lichenothelia appears, covering the rock surface with an intricate thallus of convex stroma and converging and branching superficial hyphae forming areoles. 
Diagnosis: Similar to L. umbrophila var. umbrophila but differing in forming areoles and having smaller ascospores.

Thallus saxicolous, black, of dense angular, flat to convex, on upper surface rough areoles of converging hyphae $50-100 \mu \mathrm{m}$ wide, $10-50 \mu \mathrm{m}$ high and areas with thin areoles occasionally becoming connected with one-cell-wide strands, probably margins of fusing thalli, forming together large dark areas of $10-30 \mathrm{~cm}$ across; black rough areoles are sterile when young, stromata develop convex and fertile but still hardly distinguishable from sterile areoles. Stromata ostiolate, unilocular, dispersed, black, round, oval or angular, 80-150 $\mu \mathrm{m}$ wide, $60-90 \mu \mathrm{m}$ high, paraplectenchymatous, outer cells dark brown, oval to angular, $5-8 \mu \mathrm{m}$, internal cells round to angular, 5-10 $\mu \mathrm{m}$, golden brown, center of interascal filaments embedded in gel and hardly visible, $5-8 \mu \mathrm{m}$ wide, interascal gel $\mathrm{I}+$ blue, amyloid. Asci saccate to subglobose, only 2-6 asci per stroma, 4-8 spored, ascospores biseriate, 25$35 \times 21-25 \mu \mathrm{m}$, without distinct ascus stain. Ascospores one-septate and hyaline only in early ontogeny in asci, finely verruculose, without visible halo, released or not 10.5-14.5 × 5.5-8.5 $\mu \mathrm{m}$, becoming dark brown and three-septate or occasionally submuriform to six-celled, (11-) 12.5-14.0-15.5(-16.0) $\times(7-) 7.0-7.7-$ 8.5(-9.0) $\mu \mathrm{m} \quad(\mathrm{n}=32), 1 / \mathrm{b}=(1.4-) 1.6-1.8-2.0(-2.1)$. Pycnidia not seen. Not isolated in culture.

Substrate and ecology: It occurs on conglomerate rock and granite; found only in Europe so far.

Other material examined: CZECH REPUBLIC: Southern Moravia, Znojmo District, Moravský Krumlov, hill with chapel of Sv. Florián east of the town, $49^{\circ} 2^{\prime} 51.42^{\prime \prime} \mathrm{N}, 16^{\circ} 19^{\prime} 11.12^{\prime \prime} \mathrm{E}, 305 \mathrm{~m}$, on west-facing slope with conglomerate (siliceous-calcareous) rocks, 01-IV-2011, L. Muggia L1324 \& J. Kocourková (GZU, topotype); ibidem, J. Kocourková 8563 Ẽ L. Muggia (Hb. JK \& KK, topotype).

Notes: L. umbrophila var. pullata is further distinguished here from L. umbrophila by the morphology of the thallus which forms areole-like structures of converging hyphae and by substantially smaller ascospores. We discovered this taxon during a survey carried out in Czech Republic when we were sampling fresh comparative material from Europe (Kocourková and Knudsen 2011, Muggia et al. 2013). This taxon is known only from the type locality in the Czech Republic. Lichenothelia umbrophila var. pullata builds a monophyletic clade with the two specimens collected in California. For this reason, despite some morphological differences (areole structures and smaller ascospores), we are not confident in recognizing it as separate species. Further samples and molecular analyses are needed to test whether it deserves species recognition.

\section{DISCUSSION}

Our molecular results recover Lichenothelia calcarea and L. umbrophila in monophyletic lineages whereas the other three recognized taxa are paraphyletic. Although we have increased here the taxon sampling in Lichenotheliaceae (Lichenotheliales), the family still does not receive support (Ertz et al. 2013, Hyde et al. 2013, Muggia et al. 2013). There is only partial phylogenetic resolution among the Lichenothelia species in that some samples are placed on single branches. These samples also mirror a subtle continuum of morphological differences, which hinders their certain taxonomic assignment. Our analyses of morphological characters also have highlighted variability of spore septation and size, which is not reported in the descriptions in the protologs of the species by Henssen (1987). The uncompleted fixation of genetic alleles and the lack of sufficient divergence of morphological characters likely affect the species identification in Lichenothelia. Polyphyly, paraphyly and non-reciprocal monophyly are indeed stages through which species pass before they become reciprocally monophyletic (de Queiroz 1999, 2007). Lichenothelia taxa seem to be still in this evolutionary flow.

The uncertainty encountered in the identification of Lichenothelia species also derives from the fact that most of the Lichenothelia species were described by Henssen (1987) from one or two specimens. In doing this the morphological diversity hidden in this group of fungi could not be correctly estimated. She probably was aware of these limitations in her descriptions and this might be the reason why she did not publish any determination key for the genus. Keys made from her descriptions by ourselves or by others in private use have been unsatisfactory, with many specimens impossible to determine. The genus is in strong need of revision, and any future work should include Henssen's type material together with fresh specimens collected in the type localities, on which morphological and genetic analyses should be carried out. Due to this lack of information for the majority of Lichenothelia species, we also refrain from including here a key to the genus. An additional consideration is some species of Lichenostigma subgen. Lichenogramma. It is likely that further molecular data will support the phylogenetic placement of at least some of the species in the Lichenotheliaceae and not in Lichenostigmatales. Ertz et al. (2013) has demonstrated this for the former Lichenostigma rugosum and allied taxa, and these samples are recovered in this study as a (unsupported) sister clade to Lichenothelia umbrophila.

The five analyzed Lichenothelia taxa all could occur as pioneer species on rocks; however, according to our observations, only Lichenothelia arida can be considered 
definitely a true pioneer species of harsh desert habitats in full sun in Joshua Tree National Park. There it was often the only species visible on rocks and rarely associated with lichens or other fungi. It appeared to be saprobic on mainly Aeolian particles or particles of detritus deposited by irrigation. It was a minor element in some communities beneath trees together with L. umbrophila. Lichenothelia convexa was the most common Lichenothelia in Joshua Tree National Park. This species occurs both in North America and Europe and is the only taxon that has an apparently obligate lichenicolous life style, without host specificity. Lichenothelia calcarea, L. umbrophila and L. umbrophila var. pullata are sciophilous species. They cover rock surfaces in permanent shade of long-lived trees such as oaks and pines, often spreading several meters and appearing as mineral stains. Their main source of nutrition seems to derive from rain and fog drip from the sheltering tree and the "tea" that seeps from piles of duff after rain.

Rock communities in which Lichenothelia species occur also host a multiplicity of fungi that are phylogenetically distantly related to Licheotheliaceae and present diverse living conditions. We repeatedly recovered other fungi, either by direct PCR amplifications or by culture isolation, which are closely related to plant pathogens in Capnodiales or lichenicolous fungi in Lichenoconiales or even are placed as incerta saedis in Dothideomycetes. Of note we amplified from two different samples of $L$. arida likely the same fungus that we had isolated in our former study from thalli of Lichenothelia sp. (Muggia et al. 2013). The sequences of these strains group in two (unsupported) sister clades in Capnodiales. The additional fungi either could lay on the Lichenothelia mycelia as spores or could reside on rock and intermingle their melanized hyphae with those of Lichenothelia. When culture isolates are set up the non-Lichenothelia fungi often grow faster than the true Lichenothelia strains. The identity of the Lichenothelia fungi was fully confirmed only when genetic sequences obtained from culture isolates and from the original environmental samples corresponded and grouped in Lichenotheliaceae. Morphological analyses conducted on fungal isolates indeed can hardly distinguish non-Lichenothelia from Lichenothelia fungi. RIFs strains with diverse phylogenetic affiliation share highly similar phenotypes in cultures, and these are not correlated with the growth media. Within Lichenoteliaceae the cultured Lichenothelia strains either have a yeast-like growth with almost isodiametric cells or produce filamentous hyphae with different degree of ramification. These morphologies are observed also in diverse RIFs, in cultured strains of Lichenoconiales, Lichenotheliales, Capnodiales and of those with still incerta saedis status in
Dothideomycetes (Ruibal et al. 2005, 2009; Ertz et al. 2013; Selbmann et al. 2013; Egidi et al. 2014). The absence of sexual reproductive structures further complicates the morpho-anatomical characterization of the cultured strains.

The inconspicuous morphological characters, notwithstanding their subtle diversity, shared by melanized RIFs and Lichenothelia species recall the phenomena of morphological stasis commonly detected in animals (Sturmbauer and Meyer 1992, Campillo et al. 2005, Davis et al. 2014). In morphological stasis the persistence of phenotypic traits due to developmental constraints given a rather stable but extreme environment, ensures the survival of the organisms. It seems that for RIFs and more specifically Lichenothelia fungi this would comprise the minimization of energy consumption, the inconspicuous thallus morphologies and the optional association with algae.

\section{ACKNOWLEDGMENTS}

LM thanks the Austrian Science Found for financial support (FWF project P24114-B16). JK was supported by the KONTAKT II, Program of International Cooperation in Research and Development for scientific cooperation between the CR and USA, LH 11057 from Ministry of Education, Youth and Sports. KK was supported by the grant "Environmental aspects of sustainable development of society" 42900/1312/ 3166 from the Faculty of Environmental Sciences, Czech University of Life Sciences Prague and by a co-operative agreement between UCR and Joshua Tree National Park. We thank Theodora Kopun and Sigrun Kraker (Graz) for help in lab work.

\section{LITERATURE CITED}

Ahmadjian V. 1967. The lichen symbiosis. Massachusetts: Blaisdell Publishing Co. 250 p.

Atienza V, Hawksworth DL. 2008. Lichenothelia renobalesiana sp. nov. (Lichenotheliaceae), for a lichenicolous ascomycete confused with Polycoccum opulentum (Dacampiaceae). Lichenologist 40:87-96, doi:10.1017/S002428290 8007342

Bischoff HW, Bold HC. 1963. Phycological studies IV. Some soil algae from Enchanted Rock and related algal species. University of Texas Press 6318:1-95.

Bold HC. 1949. The morphology of Chlamydomonas chlamydogama sp. nov. Bull Torrey Bot Club 76:101-108, doi:10. $2307 / 2482218$

Bubrick P, Galun M. 1986. Spore to spore resynthesis of Xanthoria parietina. Lichenologist 18:47-49, doi:10.1017/ S0024282986000051

Campillo S, Garcia-Roger EM, Martinez-Torres D, Serra M. 2005. Morphological stasis of two species belonging to the L morphotype in the Brachionus plicatilis species complex. Hydrobiologia 546:181-187, doi:10.1007/s10 750-005-4120-7

Cubero OF, Crespo A, Fatehi J, Bridge PD. 1999. DNA extraction and PCR amplification method suitable for fresh, 
herbarium-stored and lichenized fungi. Plant Syst Evol 217:243-249, doi:10.1007/BF01084401

Darriba D, Taboada GL, Doallo R, Posada D. 2012. jModelTest 2: more models, new heuristics and parallel computing. Nat Methods 9:772, doi:10.1038/nmeth.2109

Davis CC, Schaefer H, Xia Z, Baum DA, Donoghue MJ, Harmon LJ. 2014. Long-term morphological stasis maintained by a plant-pollinator mutualism. Proc Natl Acad Sci U S A 111:5914-5919, doi:10.1073/pnas.1403157111

Dettman JR, Jacobs DJ, Taylor JW. 2003. A multilocus genealogical approach to phylogenetic species recognition in the model eukaryote Neurospora. Evolution 57:2703-2720, doi:10.1554/03-073

Egidi E, de Hoog GS, Isola D, Onofri S, Quaedvlieg W, de Vries M, Verkley GJM, Stielow JB, Zucconi L, Selbmann L. 2014. Phylogeny and taxonomy of meristematic rockinhabiting black fungi in the Dothideomycetes based on multilocus phylogenies. Fungal Divers 65:127-165, doi:10.1007/s13225-013-0277-y

Ertz D, Lawrey DJ, Common RS, Diederich P. 2013. Molecular data resolve a new order of Arthoniomycetes sister to the primarily lichenized Arthoniales and composed of black yeast, lichenicolous and rock-inhabiting species. Fungal Divers 66:113-137, doi:10.1007/s13225-0130250-9

Etayo J. 2010. Líquenes y hongos liquenícolas de Aragón. Guineana 16. p 244-250.

Friedmann EI. 1982. Endolithic microorganisms in the Antarctic cold desert. Science 215:1045-1053, doi:10.1126/ science.215.4536.1045

Gardes M, Bruns TD. 1993. ITS primers with enhanced specificity for basidiomycetes. Application for the identification of mycorrhizae and rust. Mol Ecol 2:113-118, doi:10.1111/j.1365-294X.1993.tb00005.x

Gargas A, Taylor JW. 1992. Polymerase chain reaction (PCR) primers for amplifying, sequencing nuclear $18 \mathrm{~S}$ rDNA from lichenized fungi. Mycologia 84:589-592, doi:10. $2307 / 3760327$

Gorbushina AA. 2003. Microcolonial fungi: survival potential of terrestrial vegetative structures. Astrobiology 3:543554, doi:10.1089/153110703322610636

Gueidan C, Ruibal C, de Hoog GS, Gorbushina A, Untereiner WA, Lutzoni F. 2008. A rock-inhabiting ancestor for mutualistic and pathogen-rich fungal lineage. Stud Mycol 61:111-119, doi:10.3114/sim.2008.61.11

, - Schneider H. 2011. Rock-inhabiting fungi originated during periods of dry climate in the late Devonian and middle Triassic. Fungal Biol 115:987-996, doi:10.1016/j.funbio.2011.04.002

Hafellener J. 1982. Studien über lichenicole Pilze und Flechten II. Lichenostigma maureri gen. et spec. nov., ein in den Ostalpen häufiger lichenicoler Pilz (Ascomycota, Arthoniales). Herzogia 6:299-308.

Hall TA. 1999. BioEdit: a user-friendly biological sequence alignment editor and analysis program for Windows 95/98/NT. Nucl Acid Symp Series 41:95-98.

Harutyunyan S, Muggia L, Grube M. 2008. Black fungi in lichens from seasonally arid habitats. Stud Mycol 61: 83-90, doi:10.3114/sim.2008.61.08
Hawksworth DL. 1981. Lichenothelia, a new genus for the Microthelia aterrima group. Lichenologist 13:141-153, doi:10.1017/S0024282981000182

Henssen H. 1987. Lichenothelia, a genus of microfungi on rocks. In: Peveling E, ed. Progress and problems in lichenology in the eighties. Bibl Lichenol. Vol 25. p 257-293.

Hudson RR, Coyne JA. 2002. Mathematical consequences of the genealogical species concept. Int J Org Evol 56:1557-1565.

Huelsenbeck JP, Ronquist F. 2003. MrBayes 3: Bayesian phylogenetic inference under mixed models. Bioinformatics 19:1572-1574, doi:10.1093/bioinformatics/ btg180

Hyde KD, Gareth Jones EB, Liu JK, Ariyawansa H, Boehm E, Boonmee S, Braun U, Chomnunti P, Crous PW, Dai DQ, Diederich P, Dissanayake A, Doilom M, Doveri F, Hongsanan S, Jayawardena R, Lawrey JD, Li YM, Liu YX, Lücking R, Monkai J, Muggia L, Nelsen MP, Pang K, Phookamsak R, Senanayake IC, Shearer CA, Suetrong S, Tanaka K, Thambugala KM, Wijayawardene NN, Wikee S, Wu HX, Zhang Y, Aguirre-Hudson B, Aisyah Alias S, Aptroot A, Bahkali AH, Bezerra JL, Jayarama Bhat D, Camporesi E, Chukeatirote E, Gueidan C, Hawksworth DL, Hirayama K, De Hoog S, Kang JC, Knudsen K, Li WJ, Li XH, Liu ZY, Mapook A, McKenzie EHC, Miller AN, Mortimer PE, Phillips AJL, Raja HA, Scheuer C, Schumm F, Taylor JE, Tian Q, Tibpromma S, Wanasinghe DN, Wang Y, Xu JC, Yacharoen S, Yan JY, Zhang M. 2013. Families of Dothideomycetes. Fungal Divers 63:1-313, doi:10.1007/s13225-013-0263-4

Kauff F, Lutzoni F. 2002. Phylogeny of the Gyalectales and Ostropales (Ascomycota, Fungi): among and within order relationships based on nuclear ribosomal RNA small and large subunits. Mol Phylog Evol 25:138-156, doi:10.1016/S1055-7903(02)00214-2

Knudsen K, Kocourková J. 2010. A new Lichenostigma species (Genus incertae sedis) from southern California. Bryologist 113:229-234, doi:10.1639/0007-2745-113.2.229

Kocourková J, Knudsen K. 2008. Four new lichenicolous fungi from North America. Evansia 25:62-64, doi:10. 1639/0747-9859-25.3.62

- 2011. Lichenological notes 2: Lichenothelia convexa, a poorly known roc-inhabiting and lichenicolous fungus. Mycotaxon 115:345-351, doi:10.5248/ 115.345

- - - Tucker S. 2012. A checklist of the lichenicolous biota of California. Opuscula Philolichenum 11:61-103.

Kohlmeyer J, Hawksworth DL, Volkmann-Kohlmeyer B. 2004. Observations on two marine and maritime "borderline" lichens: Mastodia tessellata and Collemopsidium pelvetiae. Mycol Prog 3:51-56, doi:10.1007/s11557-0060076-x

Lilly VG, Barnett HL. 1951. Physiology of the fungi. New York: McGraw-Hill. 464 p.

Meson-Gamer R, Kellogg E. 1996. Testing for phylogenetic conflict among molecular dataset in the tribe Triticeae (Gramiae). Syst Biol 45:524-545, doi:10.1093/sysbio/ 45.4.524 
Miadlikowska J, Kauff F, Hofstetter V, Fraker E, Grube M, Hafellner J, Reeb V, Hodkinson BP, Kukwa M, Lücking R, Hestmark G, Otalora MG, Rauhut A, Büdel B, Scheidegger C, Timdal E, Stenroos S, Brodo I, Perlmutter GB, Ertz D, Diederich P, Lendemer JC, May P, Schoch CL, Arnold AE, Gueidan C, Tripp E, Yahr R, Robertson C, Lutzoni F. 2006. New insights into classification and evolution of the Lecanoromycetes (Pezizomycotina, Ascomycota) from phylogenetic analyses of three ribosomal RNA- and two protein-coding genes. Mycologia 98:1088-1103, doi:10.3852/mycologia.98.6.1088

Muggia L, Gueidan C, Knudsen K, Perlmutter G, Grube M. 2013. The lichen connections of black fungi. Mycopathologia 175:523-535, doi:10.1007/s11046-012-9598-8 - Nelson P, Wheeler T, Yakovchenko LS, Tønsberg T, Spribille T. 2011. Convergent evolution of a symbiotic duet: the case of the lichen genus Polychidium (Peltigerales, Ascomycota). Am J Bot 98:1647-1656, doi:10.3732/ ajb.1100046

, Perez-Ortega S, Fryday A, Spribille T, Grube M. 2014. Global assessment of genetic variation and phenotypic plasticity in the lichen-forming species Tephromela atra. Fungal Divers 64:233-251, doi:10.1007/s13225-0130271-4

Onofri S, Selbmann L, Zucconi L, de Hoog GS, de los Rios A, Ruisi S, Grube M. 2007. Fungal association at the cold edge of life. In: Seckbach J, ed. Algae and cyanobacteria in extreme environments. . Dordrecht: Springer. p 735757, doi: 10.1007/978-1-4020-6112-7_40

Øvstedal DO, Smith LRI. 2001. Lichens of Antarctica and South Georgia: a guide to their identification and ecology. Studies in polar research, Cambridge: Cambridge Univ. Press. 411 p.

Page RDM. 1996. Treeview: an application to display phylogenetic trees on personal computers. Comput Appl Biosci 12:357-358, doi:10.1093/bioinformatics/12.4.357

Posada D, Crandall KA. 1998. Modeltest: testing the model of DNA substitution. Bioinformatics 14:817-818, doi:10. 1093/bioinformatics/14.9.817

Rambaut A, Drummond A. 2007. Tracer. Available from: beast.bio.ed.ac.uk/Tracer

Reeb V, Lutzoni F, Roux C. 2004. Contribution of RPB2 to multilocus phylogenetic studies of the euascomycetes (Pezizomycotina, Fungi) with special emphasis on the lichen-forming Acarosporaceae and evolution of polyspory. Mol Phylogenet Evol 32:1036-1060, doi:10.1016/ j.ympev.2004.04.012

Ronquist F, Huelsenbeck JP, van der Mark P. 2005. MrBayes 3.1 http://mrbayes.csit.fsu.edu/mb3.1_manual.pdf

Ruibal C, Gonzalo P, Bills GF. 2005. Isolation and characterization of melanized fungi from limestone formation in Mallorca. Mycol Prog 4:23-38, doi:10.1007/s11557-0060107-7

—, Gueidan C, Selbmann L, Gorbushina AA, Crous PW, Groenewald JZ, Muggia L, Grube M, Isola D, Schoch CL, Staley JT, Lutzoni F, de Hoog GS. 2009. Phylogeny of rock-inhabiting fungi related to Dothideomycetes. Stud Mycol 64:123-133, doi:10.3114/sim.2009.64.06

Schoch CL, Crous PW, Groenewald JZ, Boehm EWA, Burgess TI, de Gruyter J, de Hoog GS, Dixon LJ, Grube M,
Gueidan C, Harada Y, Hatakeyama S, Hirayama K, Hosoya T, Huhndorf SM, Hyde KD, Jones EBG, Kohlmeyer J, Kruys Å, Li YM, Lücking R, Lumbsch HT, Marvanová L, Mbatchou JS, McVay AH, Miller AN, Mugambi GK, Muggia L, Nelsen MP, Nelson P, Owensby CA, Phillips AJL, Phongpaichit S, Pointing SB, Pujade-Renaud V, Raja HA, Rivas Plata E, Robbertse B, Ruibal C, Sakayaroj J, Sano T, Selbmann L, Shearer CA, Shirouzu T, Slippers B, Suetrong S, Tanaka K, Volkmann-Kohlmeyer B, Wingfield MJ, Wood AR, Woudenberg JHC, Yonezawa H, Zhang Y, Spatafora JW. 2009. A class-wide phylogenetic assessment of Dothideomycetes. Stud Mycol 64: 1-15, doi:10.3114/sim.2009.64.01

Selbmann L, de Hoog GS, Mazzaglia A, Friedmann EI, Onofri S. 2005. Fungi at the edge of life: cryptoendolithic black fungi from Antarctic desert. Stud Mycol 51:1-32, doi:10.3390/biology2020784

, Grube M, Onofri S, Isola D, Zucconi L. 2013a. Antarctic epilithic lichens as niches for black meristematic fungi. Biology 2:784-979, doi:10.3390/biology2020784

- Isola D, Egidi E, Zucconi L, Gueidan C, de Hoog GS, Onofri S. 2013b. Mountain tips as reservoir for new rockfungal entities: Saxomyces gen. nov. and four new species from the Alps. Fungal Divers 65:167-182, doi:10.1007/ s13225-013-0234-9

Stamatakis A, Ludwig T, Meier H. 2005. RAxML-iii: a fast program for maximum likelihood-based inference of large phylogenetic trees. Bioinformatics 21:456-463, doi:10. 1093/bioinformatics/bti191

Sterflinger K. 2006. Black yeast and meristematic fungi: ecology diversity and identification. In: Peter G, Rosa C, eds. The yeast handbook: biodiversity and ecophysiology of yeasts. Berlin: Springer. p 501-514, doi: 10.1007/3-54030985-3_20

Sturmbauer C, Meyer A. 1992. Genetic divergence, speciation and morphological stasis in a lineage of African cichlid fishes. Nature 358:578-581, doi:10.1038/358578a0

Trent DD, Hazlett RW. 2002. Joshua Tree National Park geology. Joshua Tree National Park Association. 66 p.

U.S. Climate data. http://www.usclimatedata.com/climate/ joshua-tree/california/united-states/usca1645, accessed $12 / 11 / 2014$.

Vilgalys R, Hester M. 1990. Rapid genetic identification and mapping of enzymatically amplified ribosomal DNA from several Cryptococcus species. J Bacteriol 172:4238-4246, doi:0021-9193/90/084238-09\$02.00/0

White TJ, Burns TD, Lee S, Taylor J. 1990. Amplification and direct sequencing of fungal ribosomal DNA genes for phylogenies. In: Innis MA, Gelfand DH, SniskyJJ, White TJ, eds. PCR protocols: a guide to methods and applications. San Diego, California: Academic Press. p 315-322.

Wijayawardene NN, Crous PW, Kirk PM, Hawksworth DL, Boonmee S, Braun U, Dai DQ, D'souza MJ, Diederich P, Dissanayake A, Doilom M, Hongsanan S, Gareth Jones EB, Groenewald JZ, Jayawardena R, Lawrey JD, Liu JK, Lücking R, Madrid H, Manamgoda DS, Muggia L, Nelsen MP, Phookamsak R, Suetrong S, Tanaka K, Thambugala KM, Wanasinghe DN, Wikee S, Zhang Y, Aptroot A, Ariyawansa HA, Bahkali AH, Jayarama Bhat D, Gueidan C, Chomnunti P, Sybren De Hoog G, 
Knudsen K, WJ Li, McKenzie EHC, Miller AN, Phillips AJL, Piątek M, Raja HA, Shivas RS, Slippers B, Taylor JE, Tian Q, Wang Y, Woudenberg JHC, Cai L, Jaklitsch WM, Hyde KD. 2014. Naming and outline of Dothideomycetes 2014 including proposal for the protection or suppression of generic names. Fungal Divers 69:1-55, doi:10.1007/s13225-014-0309-2

Zhou S, Stanosz GR. 2001. Primers for amplification of $\mathrm{mt}$ SSU rDNA and a phylogenetic study of Botryosphaeria and associated anamorphic fungi. Mycol Res 105:10331044, doi:10.1017/S0953756201004592

Zhurbenko M. 2008. A new species from the genus Lichenothelia (Ascomycota) from the northern Ural. Mikol Fitopatol 42:240-243.

Zoller S, Scheidegger C, Sperisen C. 1999. PCR primers for the amplification of mitochondrial small subunit ribosomal DNA of lichen-forming ascomycetes. Lichenologist 31:511-516, doi:10.1017/S0024282999000663 